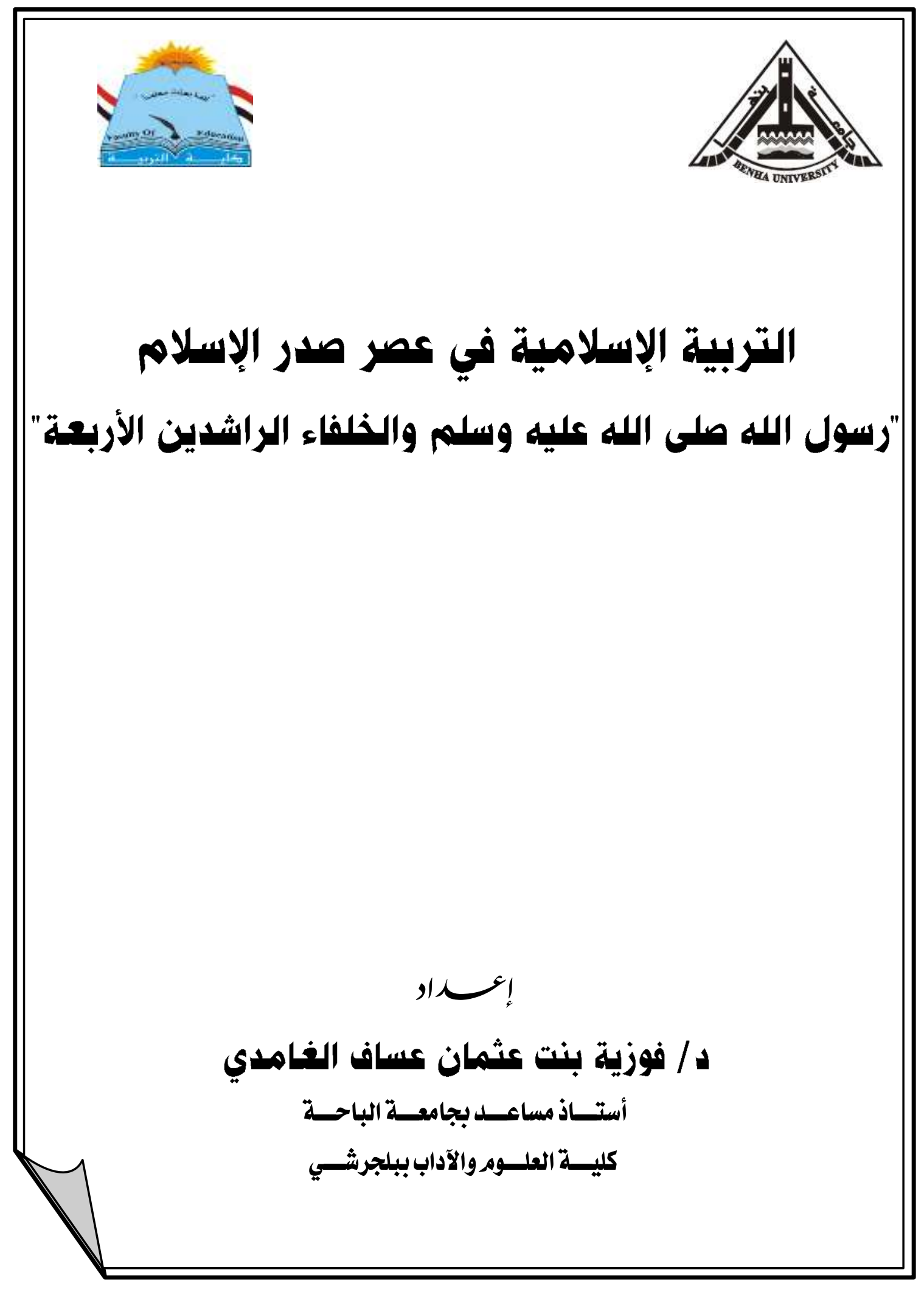




\section{التربية الإسلامبة في عصر صدر الإسلام "رسول الله صلى الله عليه وسلم والخلفاء الراشدين الأربعة" إ}

ه/ فوزية بنت عثمان عساف الغامدي

أستــاذ مساعــل بجامعــة الباحسـة

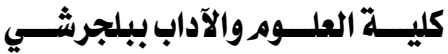

\section{ملنــص الدراسبسة}

تهدف الدراسـة الحاليـة إلى الوقوف على ملامـح التربيـة الاسـلامية في عصر صدر

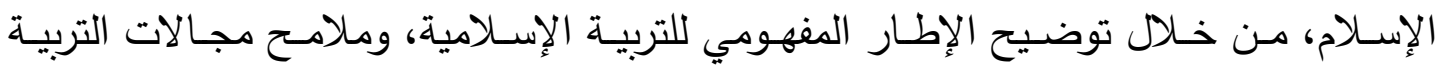

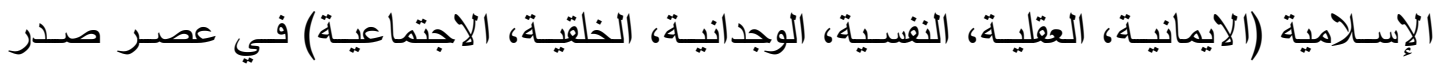

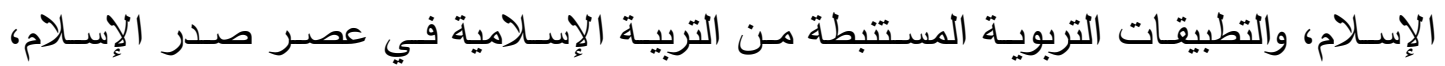
واستخدمت الباحثة المنهج الوصفي والمنهج الاستتباطي، وأظهرت الدراسة عدة نتائج أهمها: ،

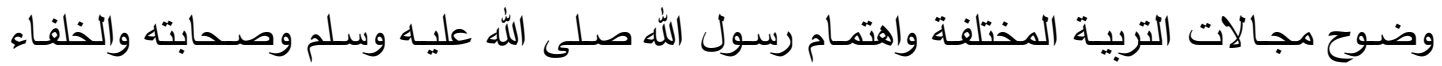
الراشـدين مـن بعده بهـا؛ فـاهتموا بالتربيـة العقليـة والتربيـة العقديـة والتربيـة النفسـية والتربيـة الاجتماعية والتربية الخلقية والتربية الصحية والتربية الفكرية، كما أثارت الدراسة في نتائجها إلى الى تطبيقات تربوية مستتبطة والتي يمكن تطبيقها في المؤسسات التربوية وهي: (الاتصال بأولياء

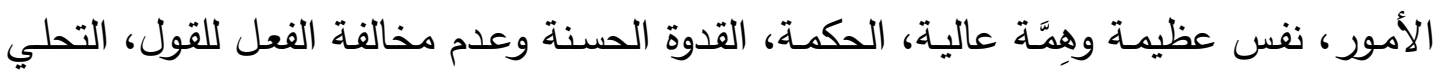

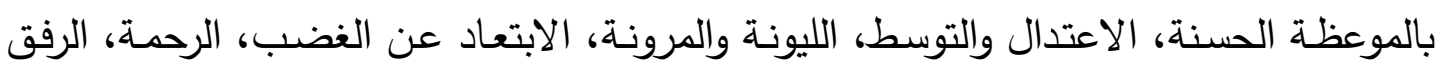
واللين، الحلم والأناة).

الكلمات المفتاحية: التربية- التربية الاسلامية- عصر صدر الاسلام. 


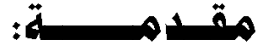

إنّ التربية بمجالاتها على الرغم من اختلافها وتتوّعها، لا موضوع لها، إلا أن يدلي العقل بقراره عن حقيقة الإنسان والكون والحياة؛ فلا يوجد ذالك الذي ينبغي إخضاع الرغائب الوجدانيّة والثهوانيّة، من أجله وفي سبيله.

وقد انتهى المنهج العلمي للمعرفة، إلى أنّ الإنسان عبد مملوك لله ميّزه عن سـائر المخلوقات بالتكريم وقابليّة المعرفة والعلم، وإلى أنّ الكون الذي يراه من حوله مخلوقات مسخّرة

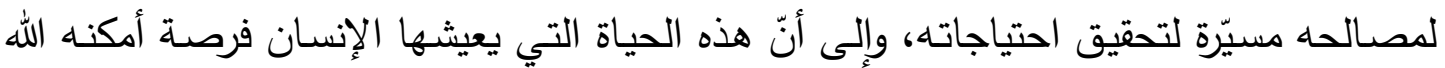

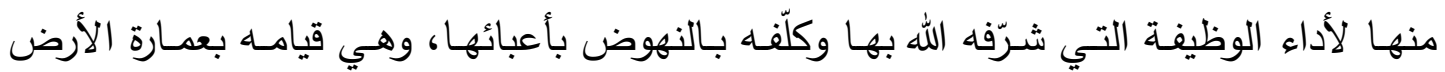

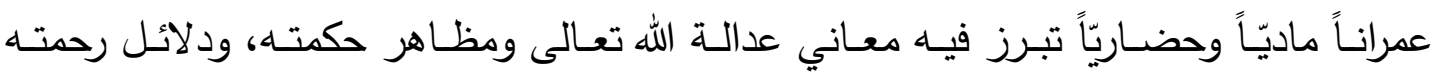

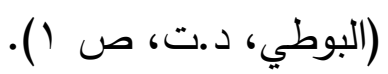

إن القـرآن الكـريم هـو سـبيل الرشـاد والهـدى لكافـة النـاس أجمعين، قـال الله تعـالى

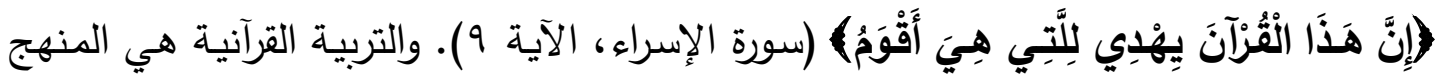
المتكامل ويتحقق به التوازن والتوافق بين الإنسان ونفسه، وبينه وبين المجتمع الذي يعيش فيه، الديه

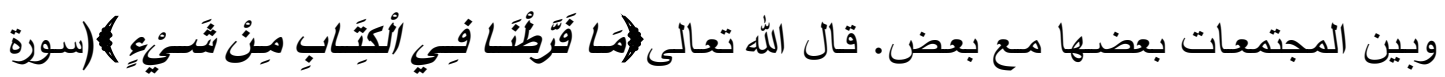

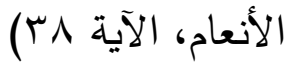

لقد كانت بعثة رسول الله صلّى الله عليه وسلّم تحقيقاً وتجسيداً للسبيل إلى كلّ منهما. لقد كان القرآن الذي تنزّل عليه وحياً بألفاظه ومعانيه، هو الدصدر الأوّل للمعرفة وهو المبمِّر

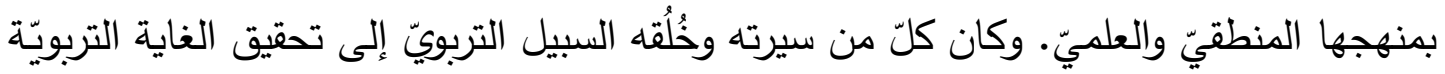
المتّقق عليها في العالم كلّه، وهي إخضاع العواطف والرغائب الشهوانيّة لقرارات العقل وحكمهـ؛

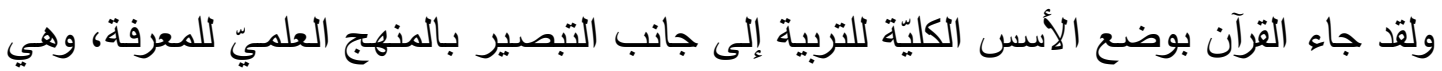
ما يعبّر عنه بالتزكية، أي تطهير النفوس من الرعونات وتحريرها من أسر الأهواء المحرّمة، وما

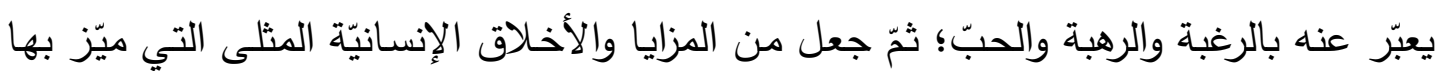

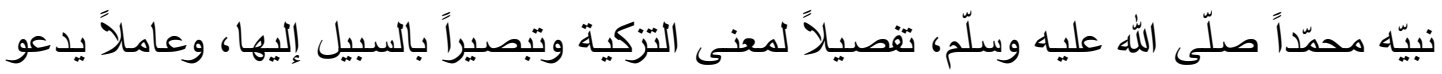

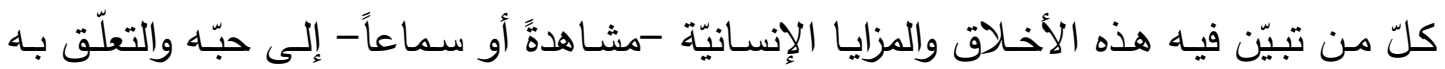

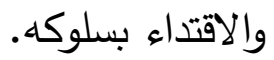

حيث أجمعت العديد من الدراسات والبحوث على أن التربية الإسلامية في ضوء القرآن

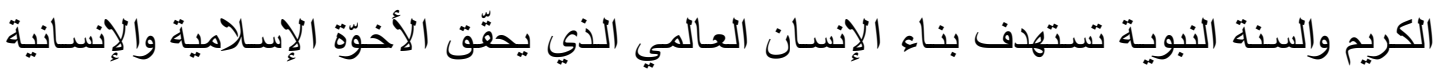




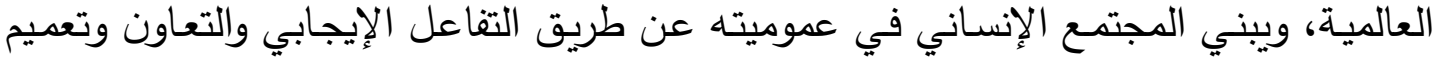

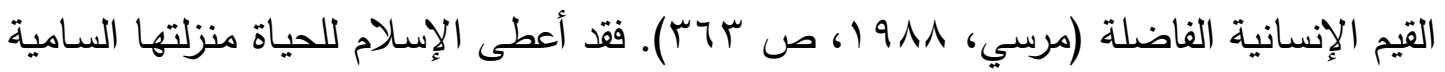

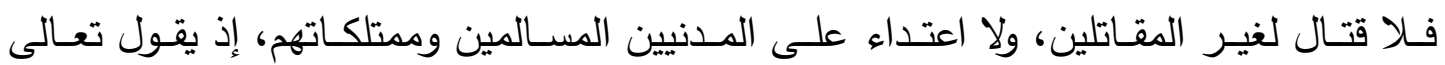



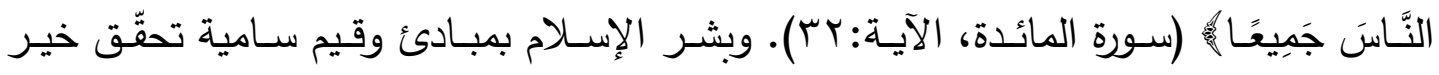

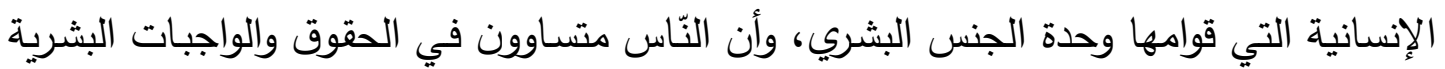

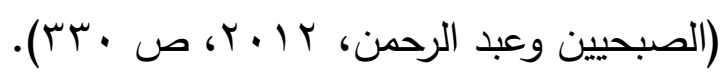

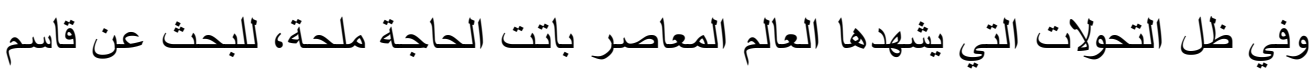

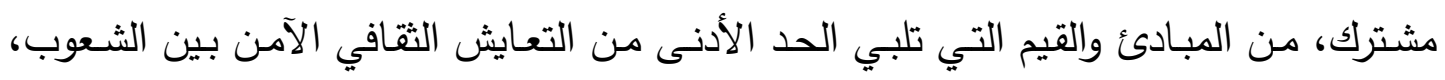

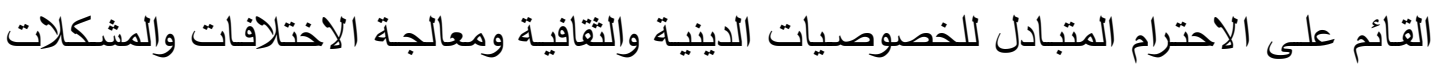

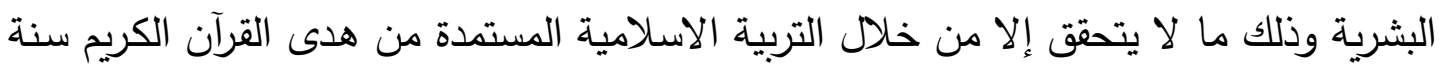

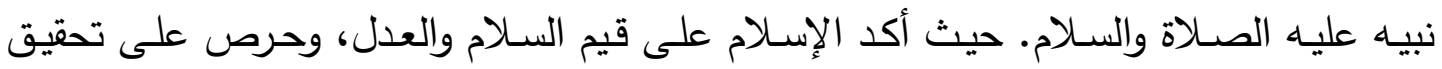

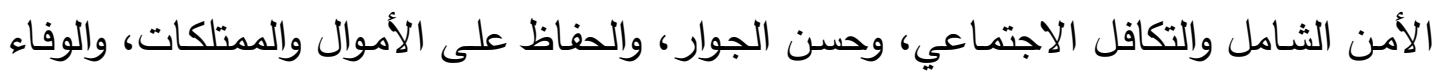

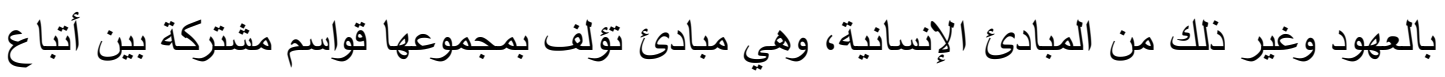

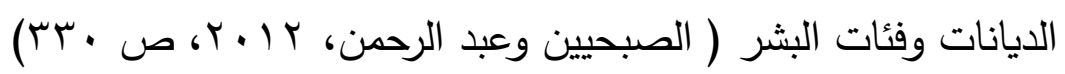

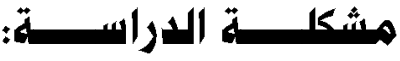

تثير كثير من الدراسات في مجتمعاتتا الإسلامية إلى وجود مشكلات مستحدثة لم نعهدها من قبل ومنها: محاولات تشويه الإسلام وربطه بالتخلف، وظواهر الإرهاب، والإدمان، والبطالة،

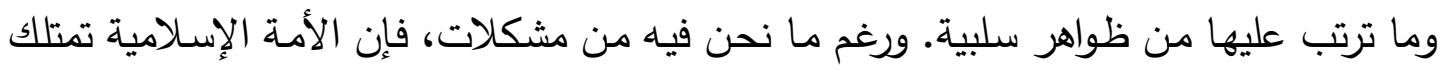

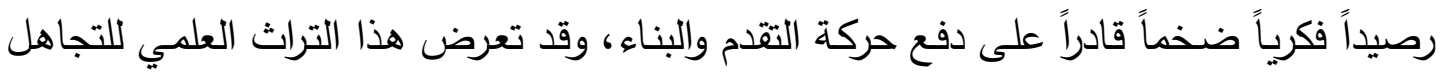

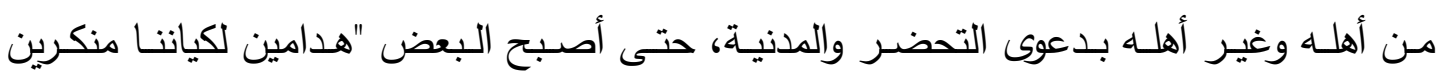

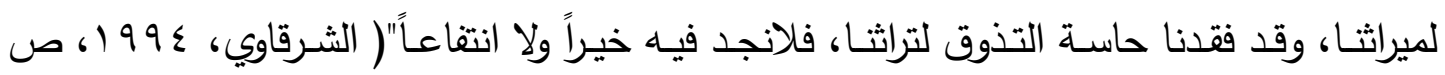

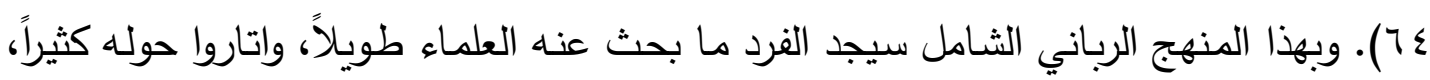

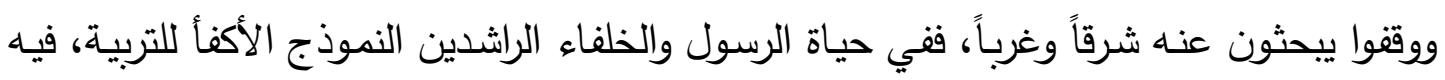

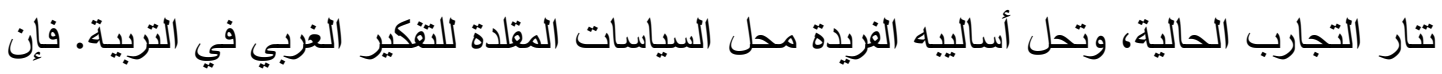

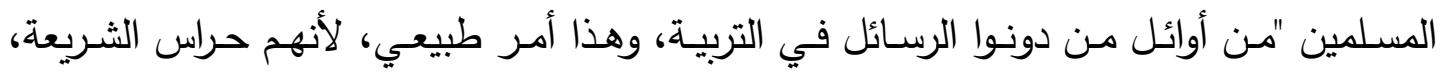

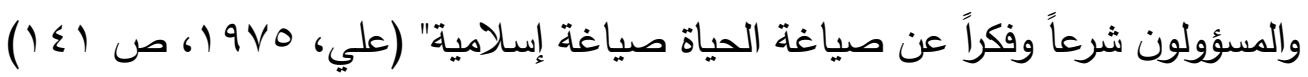




\section{أسئلمبـة الدراستسلة:}

ومما سبق تتبلور مشكلة الدراسة في الاجابة عن السؤال الرئيس التالي:

× ما ملامح التربية الاسلامية في عصر صدر الإسلام ؟ ومنه تتفرع الأسئلة الفرعية التالية:

س ا ما الإطار المفهومي للتربية الإسلامية؟

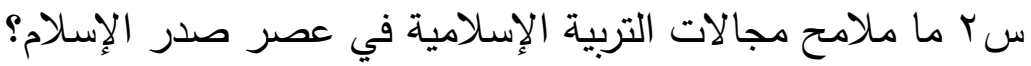

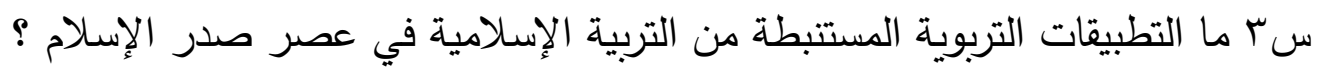

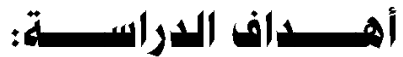

1-توضيح الإطار المفهومي للتربية الإسلامية.

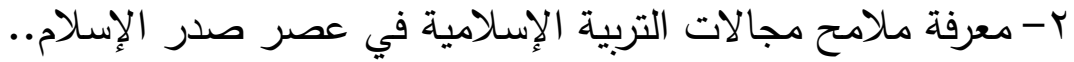

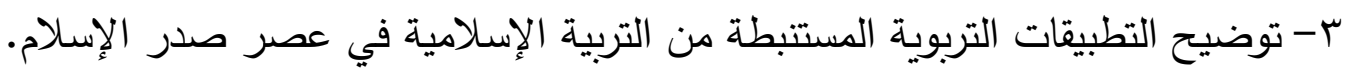

\section{جسدود الدراسـالة:}

تقتصر الدراسة الحالية على الفترة الزمنية منذ بداية بعثة الرسول صلى الله عليه وسلم

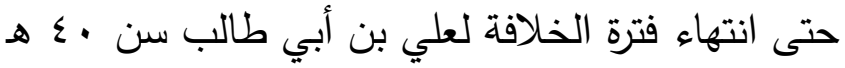

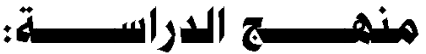

سوف تستخدم الدراسة الحالية المنهج التاريخي "المقصود بالمنهج التاريخي كما عرفه الدكتور أحمد بدر : يقوم هذا الدنهج أساساً على دراسة أحداث وأحوال الماضي إما بالسرد فقط

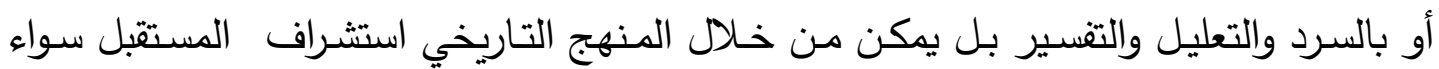

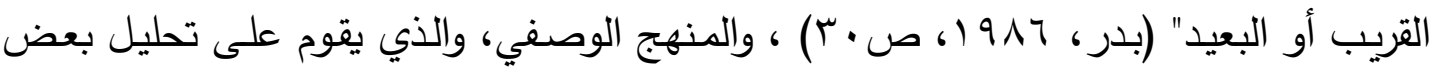

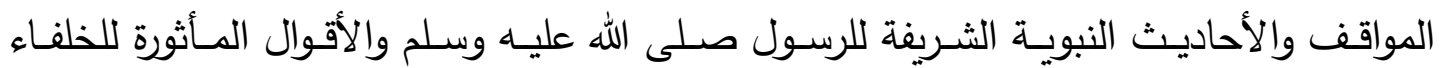
الراشدين الأربعة: أبو بكر الصديق وعمر بن الخطاب وعثمان بن عفان وعلي بن أبي طالب.

\section{مصطلحات ومفاهيم الدراسة:}

تعريف التربية: أولًا في اللغة:

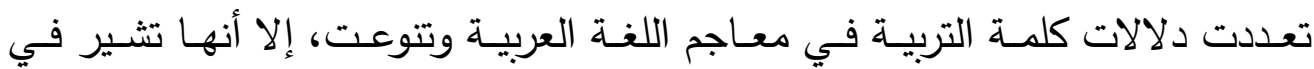

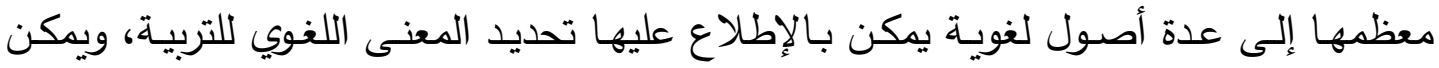

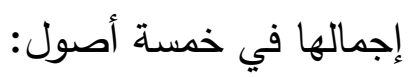




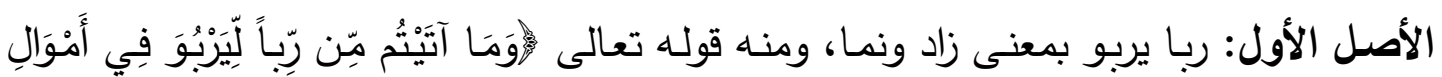

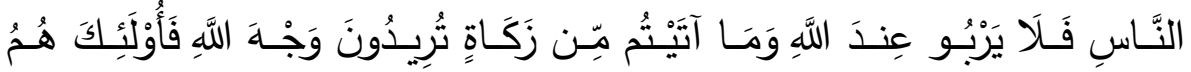

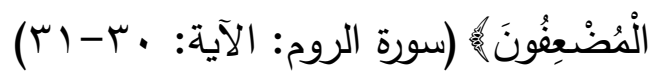

$$
\begin{aligned}
& \text { الأصل الثاني: "أن تكون بمعنى نشأ وترعرع . }
\end{aligned}
$$

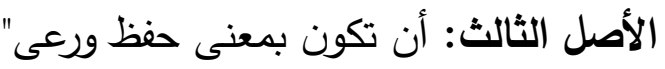

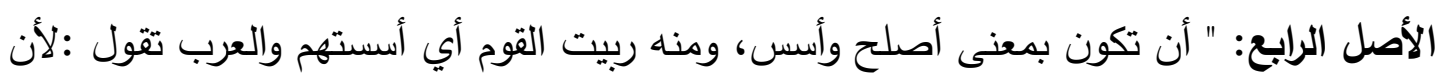

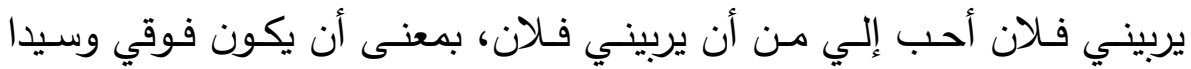

$$
\text { يملكني }
$$

الأصل الخامس: الرسوخ في العلم ومنه العالم الرباني أي الراسخ في العلم" .

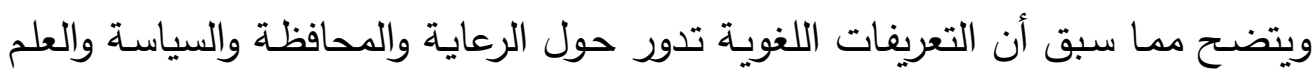



\section{ثانيًا في الاصطلاح:}

فالتربيـة هي: "العمليـة المقصودة أو غير المقصـودة التي اصطنعها المجتــع لتتشئة

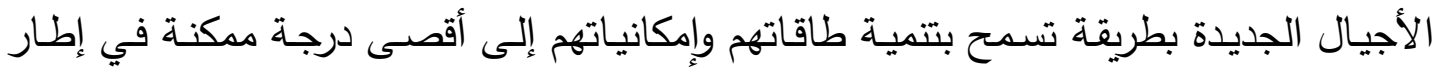

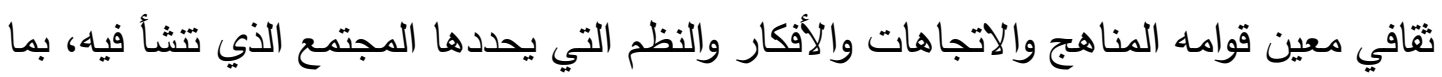

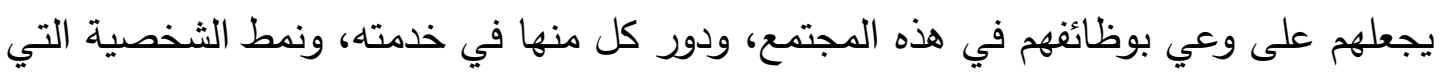

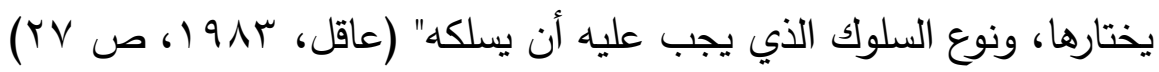
وفي اصطلاح علماء التربية الحديثة فهي عند جون ديوي(

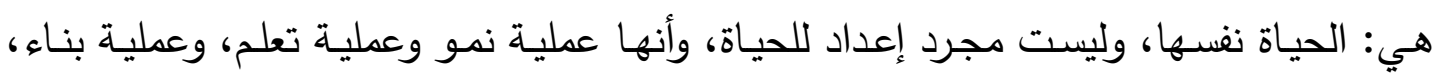
وتجديد مستمرين للخبرة، وعملية اجتماعية".

وقد ورد عن المؤتمر الذي عقد تحت رعاية اللجنة الدولية للتربية تقرير بعنوان: نعلم

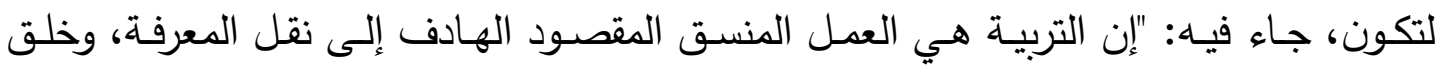

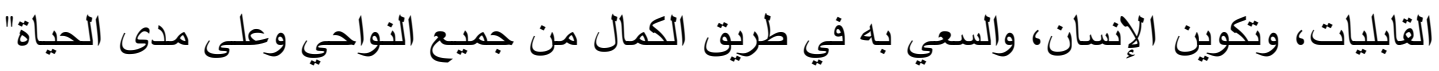

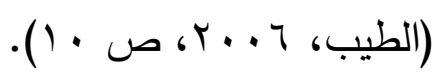

وورد في الموسوعة العربية العالميـة: أن التربية "تعبير يقصد به تنشئة الفرد المسلم

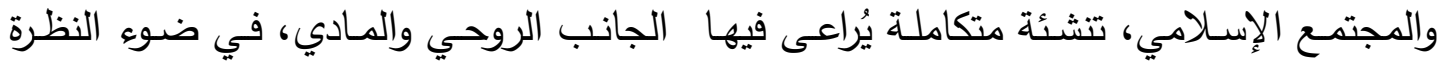


الإسـلامية الثاملة، وهي تُعنى بالفرد وإعداده لحل مشاكله، ومدى نجاحه في تحقيق رغباتها

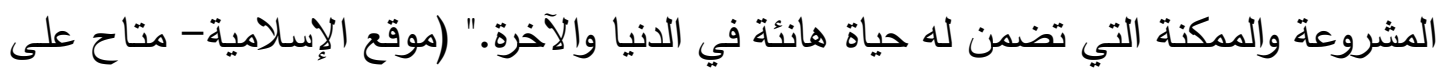
(http://www.almualem.net/saboora/forumdisplay.php?f=8

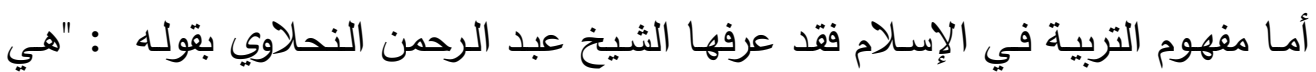

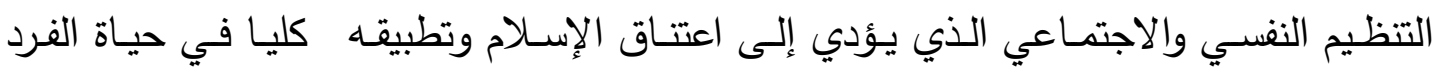
والجماعة، أو بمعنى آخر هي تتمية فكر الإنسان وتتظيم سلوكه وعواطفه على أساس الدين الإسل الإسلامي بقصد تحقيق أهداف الإسلام في حياة الفرد والجماعة في كل مجالاتهات الإنسات الحياة".

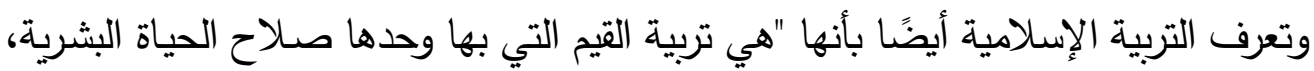

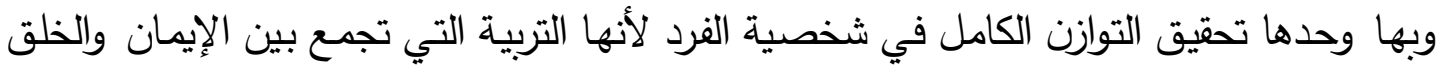

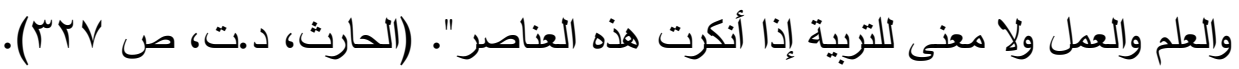

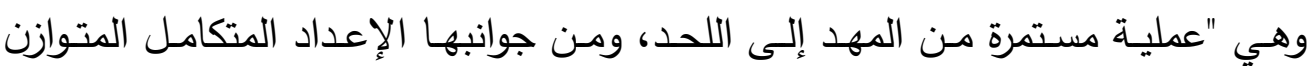

$$
\text { للدارين، فهي منهج لإعداد الإنسان لدنياه ولآخرته" }
$$

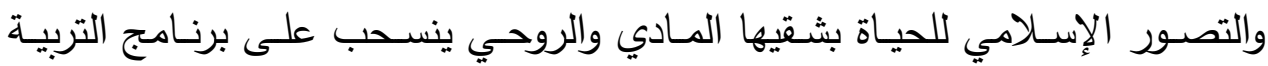
الإسلامية؛ إذ يهتم بالكيان الروحي للفرد بجانب الكيان المادي، وإعداده لحل مشاكله المادية

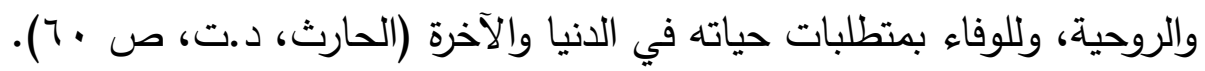
ومن التعريفات السابقة يتضح أن هناك الفرق واضحا بين التربية بشكل عام، والتربية الإسلامية بشكل خاص، وربما يمكننا أن نحدد الفرق الفاصل بين التربيتين: أن التربية العامة لم لم الم التين

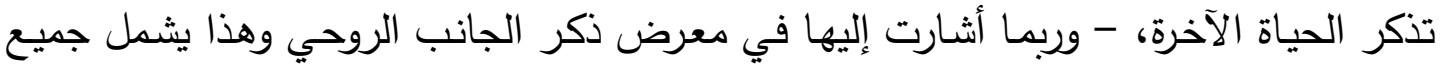

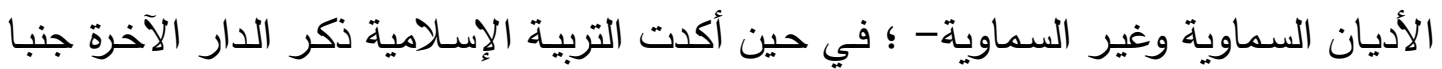
على جنب ميع الحياة الدنيا التي هي معبر إليها.ومنهج التربية العامة يختلف من مجتمع إلى التى مجتمع، بينمـا هـو موحد في المجتمعـات الإسـلامية ويستقي تعليماتـه مـن مصـادر التربيـة الإسلامية وهي القرآن الكريم، والسنة المطهرة. والباحثة في دراستها هذه يتناول جانب التربية من حيث هي إسلامية، وبما يتقق معها من التربية العامة تاركا ما يتناقض مع التربية الإسلامية

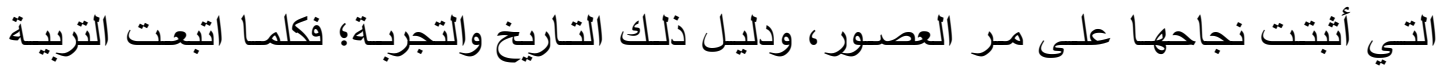

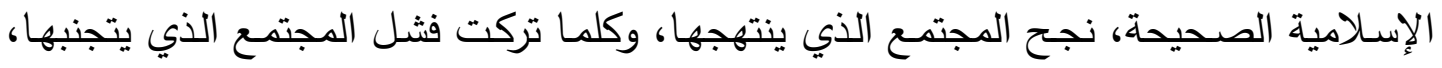
وواقع العالم الحاضر خير دليل على ذلك. 


\section{المبحث الأول \\ الإطار المفهومي للتربية الإسلامية}

في هذا المبحث تجيب الباحثة عن السؤال الأول من الدراسة وهو ما الإطار المفهومي

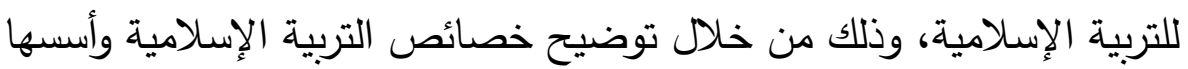

المطلب الأول: ذصائص التربية في عصر صدر الاسلاه:

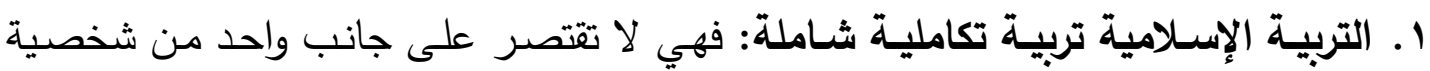

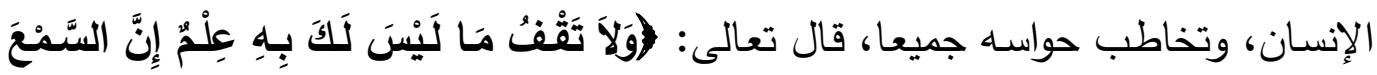

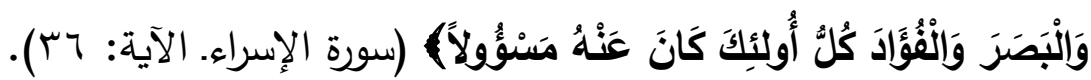
وتدعو إلى الاهتمام بالجسم ونظافته والعناية باه، وتأمر العقل بالنظر في ملكوت الأهراه

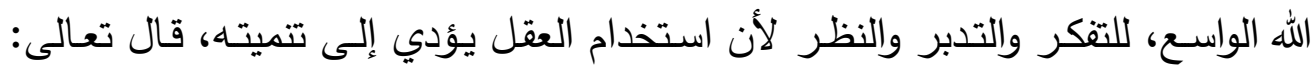

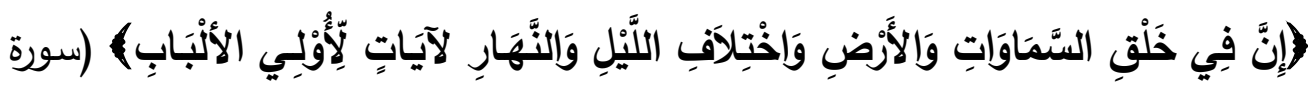
آل عمران، الآية: .9 (19). وتهتم بالروح والنفس فوجهتها للعبادة التي تهذب النهابه النفس وتسمو بالروح قال تعالى:

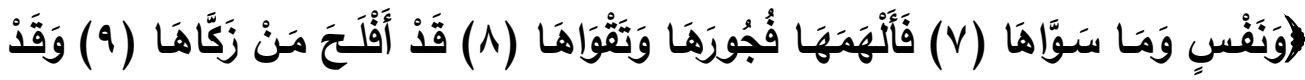

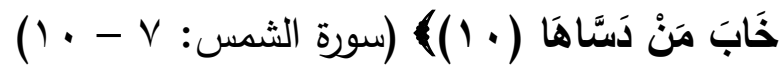
r. التربية الإسلامية تقوم على الإيمان بالله عز وجل: تدعو الإنسان أول ما تدعوه إلى اليقين

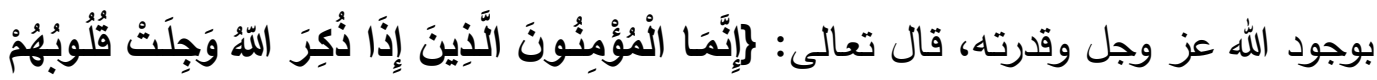

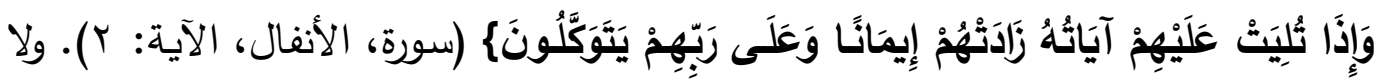

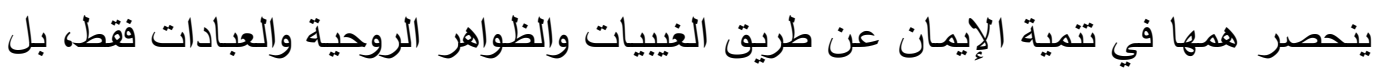

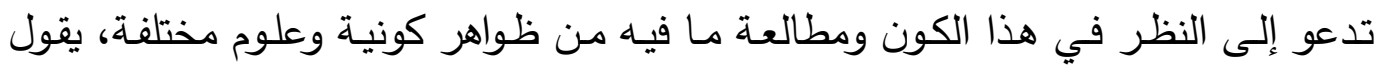

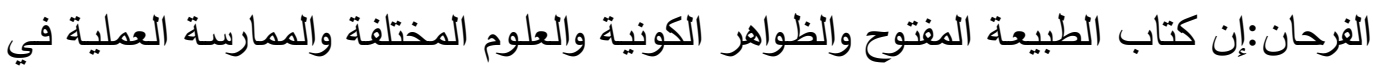
الحياة كلها تعزز هذا الإيمان وترتبط به أيما ارتباط. r. التربية الإسلامية تربية عملية: تؤكد التربية الإسلامية على الجانب التبانب العملي في حياة الفرد

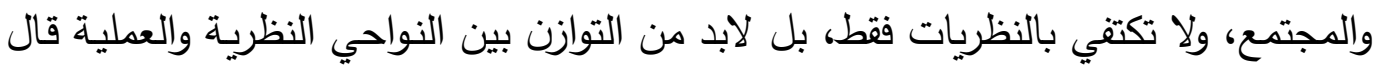






وشجع عليه وبين أن الإيمان مرتبط ارتباطا وثيقا بالعمل، وبين أن الإنسان يجزى بما عمل

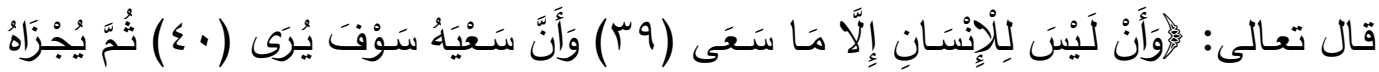

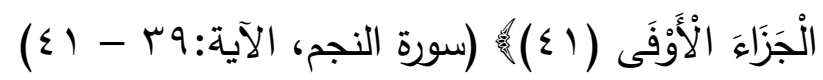

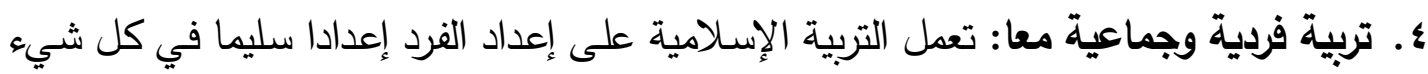
وتعتبره مسؤولا عن تصرفاته وحياته، وتمنحه الحرية في كل الأمور ضمن الضوابط الشرعية الضية

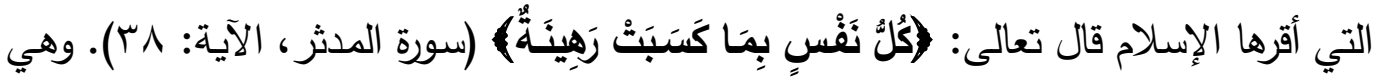

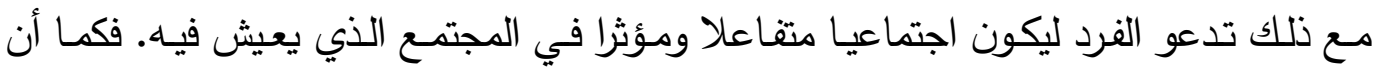
الإنسان مسؤول عن نفسه فهو مطالب بالانتماء إلى الجماعة والتفاعل معها تفاعلا إيجابيا. ه. التربية الإسلامية تنمي في الإنسان الرقابة الذاتية على عمله: فتجعله يشعر برقابة الله



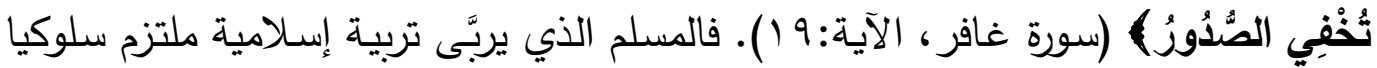
وأخلاقيا في كل وقت وفي كل حين لأنه يعلم أن الله يراقبه ومطلع على أعماله.

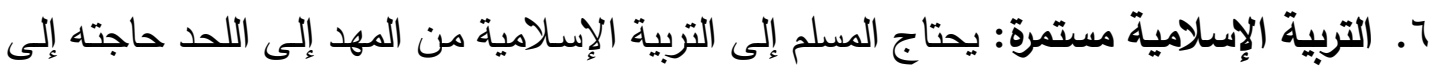

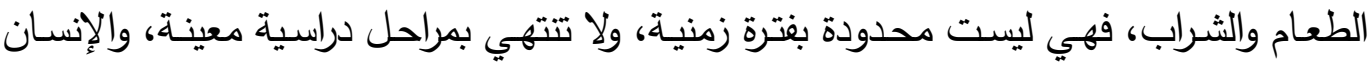

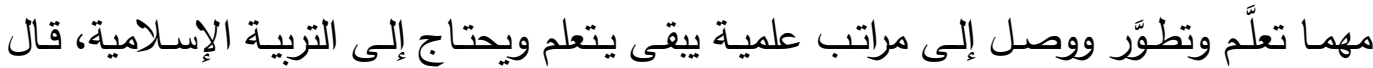

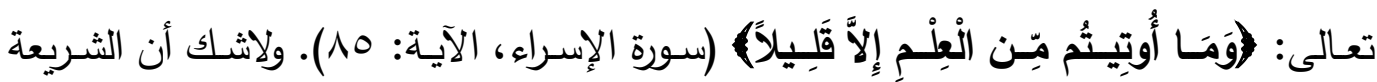

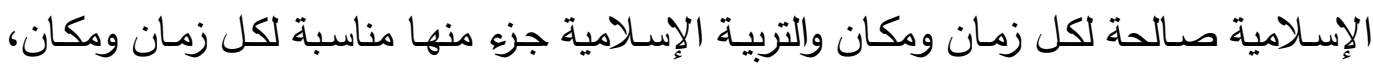
وبالتالي فهي مستمرة ومتتابعة لا تتوقف أبدا، والإنسان محتاج إليها في كل مراحل حياته. قد

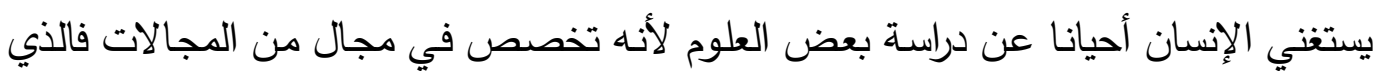

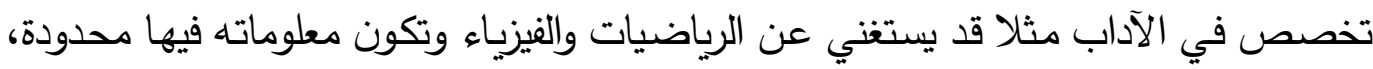
والعكس كذلك فقد يستغني المتخصص في المجالات العلمية عن التاريخ أو الفلسفة، ولكن الجميع لا يمكن أن يستغنوا عن دينهم ولا أن يستغنوا عن التربية الإسلامية.

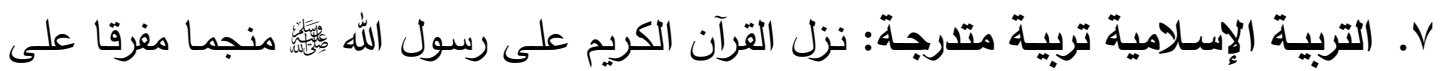

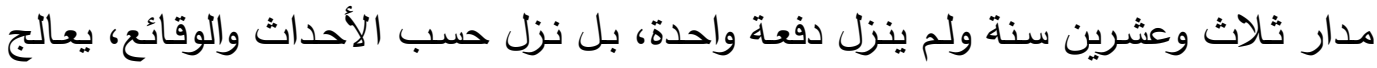

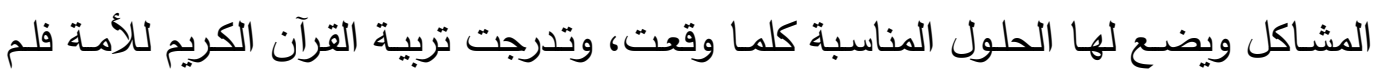
يطالب الناس بكل الأحكام الثرعية دفعة واحدة، فكان التدرج في فرض الجهاد، وتحريم 
الخمر ، وفرضت العبادات على مراحل ولم تفرض مرة واحدة، فكانت الصـلاة في السنة

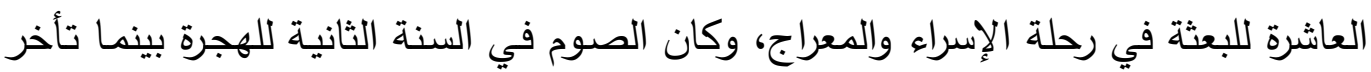

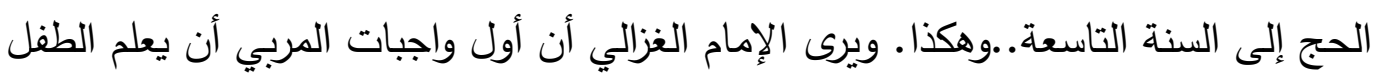

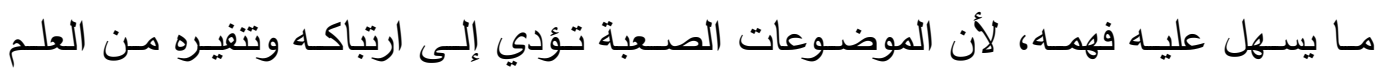



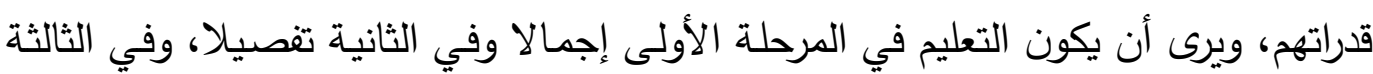
تعميقا بدراسة ما استشكل في العلوم ووسائل الخلف فيه (ابن خلدون، د.ت، ص صل • (1).

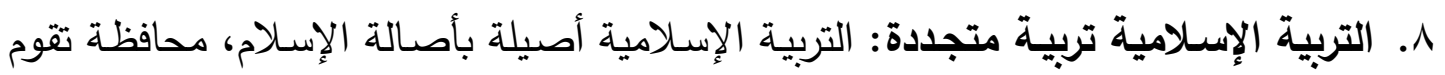

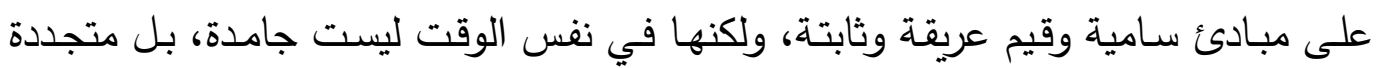

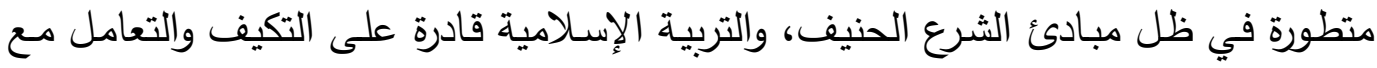

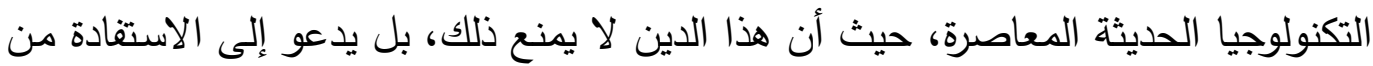

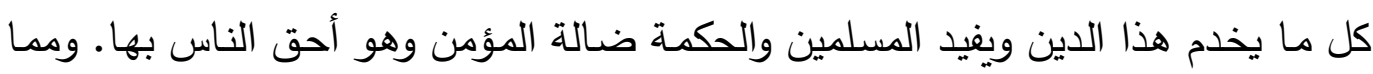

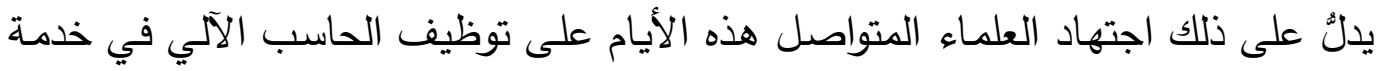

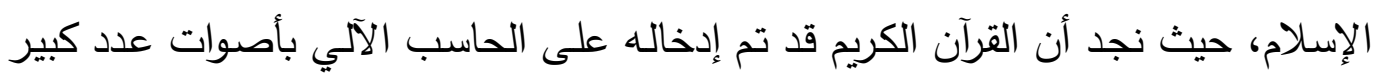

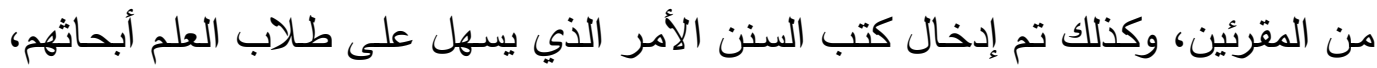

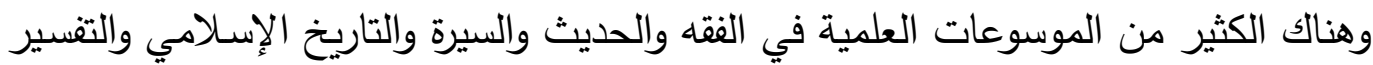

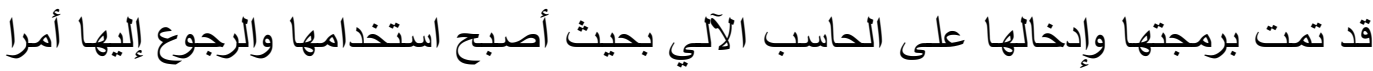
في غاية السهولة، بالإضافة إلى المواقع الإسلامية الكثيرة على الثبكة العالمية للمعلومات (الإنترنت) وباللغات المختلفة مما يسهل نشر الإسلام والدعوة إليه.

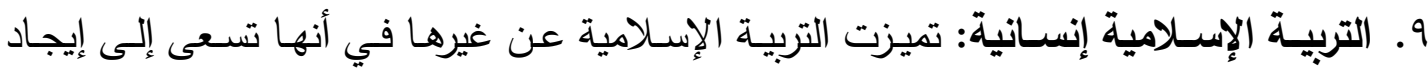

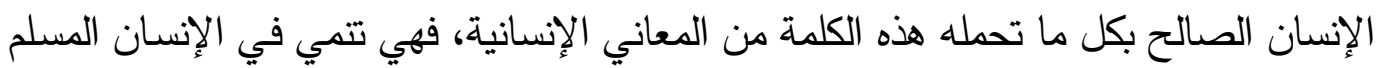

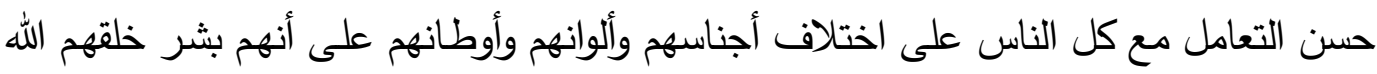

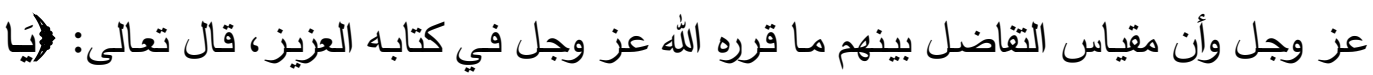

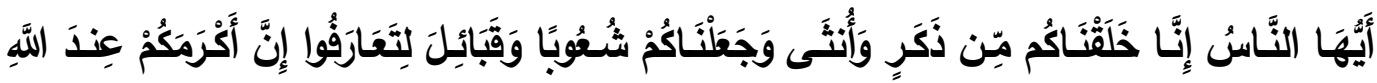

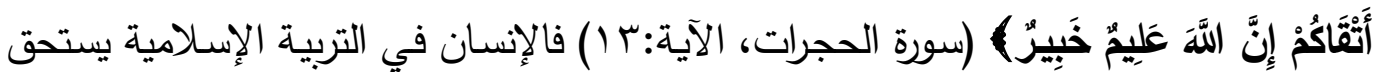
الاحترام بصفته الإنسانية على عكس ما يحصل في غير التربية الإسلامية، وكثيرا ما نسمع في 
بعض أثـكال التربيـة عن المـواطن الصـالح، والحقيقـة أن هنـاك فرقا بين الإنسـان الصـالح

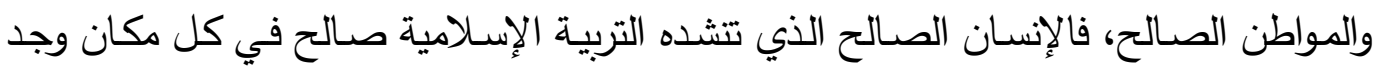

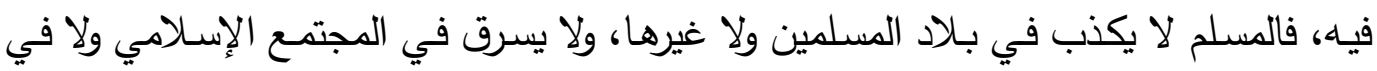

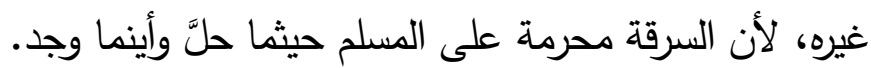
•

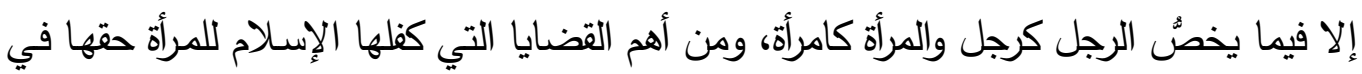

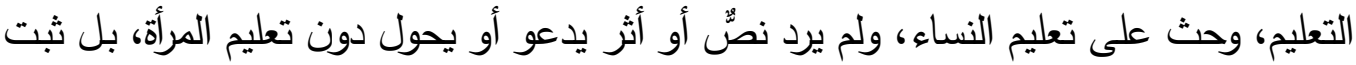

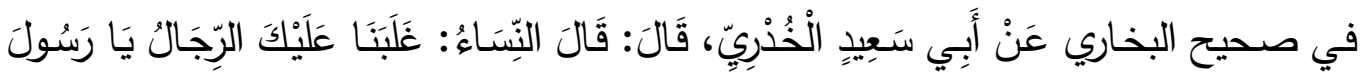

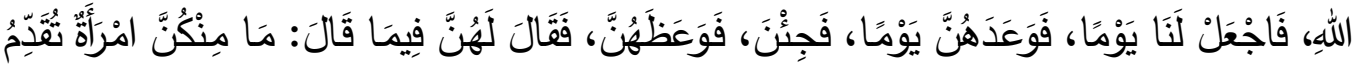

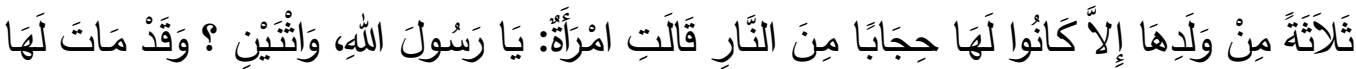

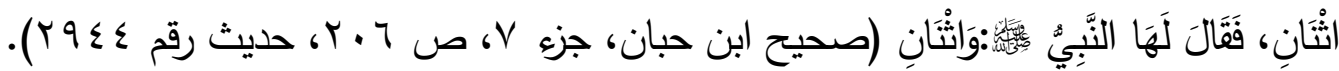
I ا التربيـة الإسـلامية متاحسة للجميع دون تفريـق: إن فرص التعليم في العالم الإسـلامي كانت

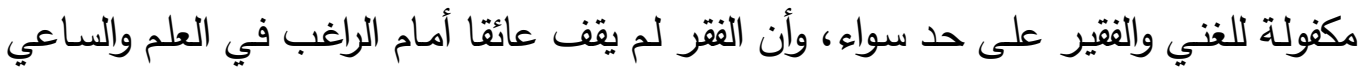


لاستقبال الطلبة بالمجان دون قيد أو شرط. والتربية لا يمكن أن تكون عملية إقليمية ضيقة،

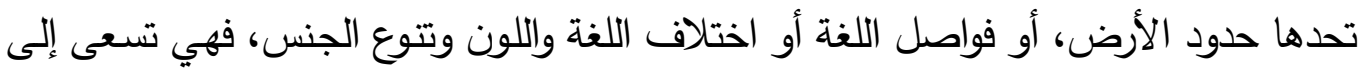

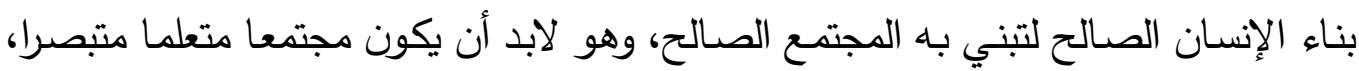
يستشعر الفرد فيه معنى الأخوة الإنسانية ويعتز به ويصونه ويحافظ عليه. وعلى ذلهان ذلك فالمساواة



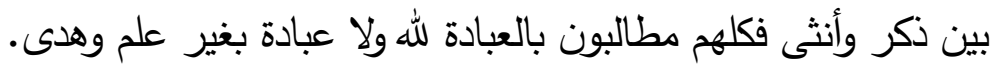

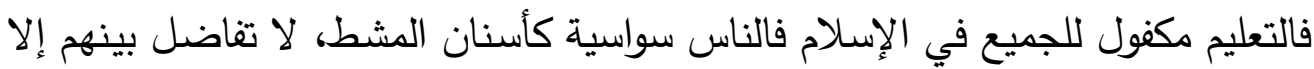

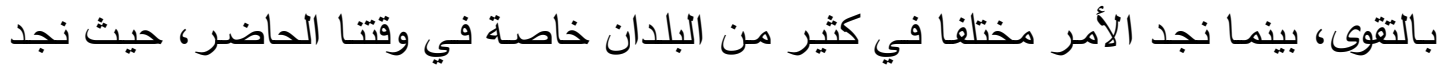
التمييز القاتل بين الناس فيحرم بعضهم من العلم بسبب عدم قدرتهم على الالتحاق بالددارس

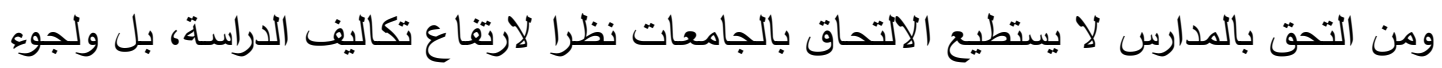

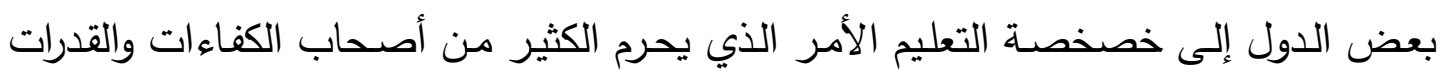
العلمية من تحصيل العلم بالثكل الصحيح.ويحرم الأمة من قدراتهم وإمكاناتهر. 


\section{المطلب الثاني أسس التربية في عصر صدر الإسلام}

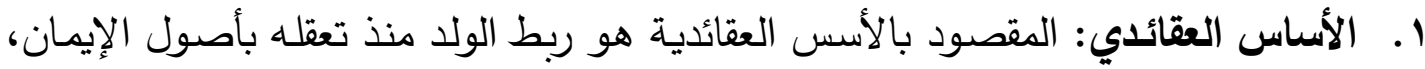

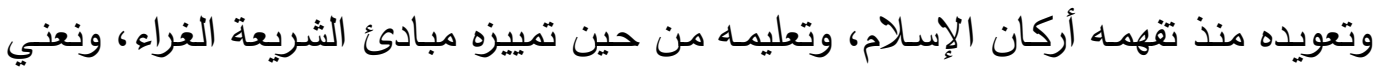

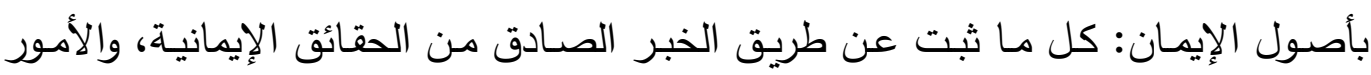
الغيبية: كالإيمان بالله سبحانه، والإيمان بالملائكة، والإيمان بالكتب السماوية، والإيمان الإنان

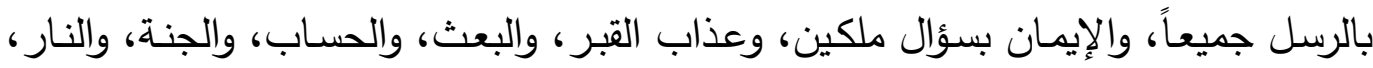

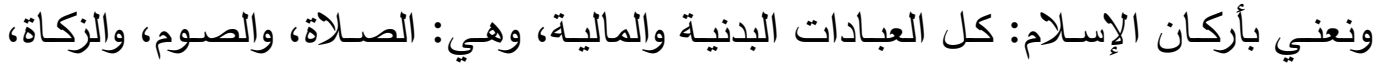

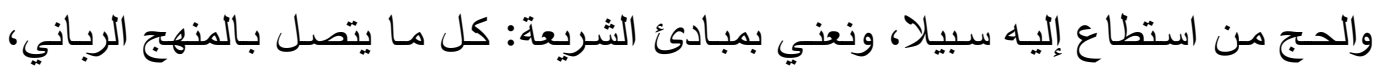

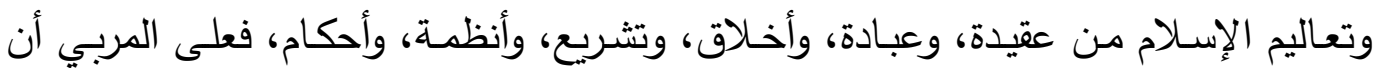

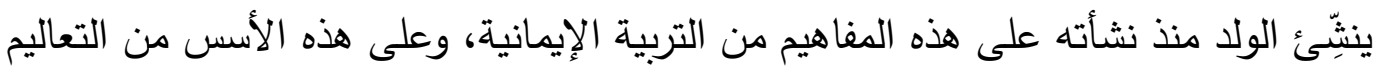

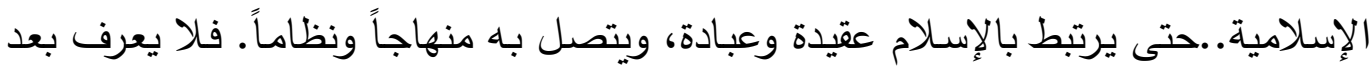

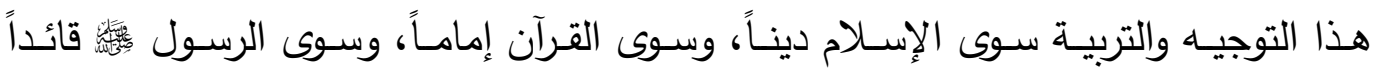
وقدوة... وهذا الشمول لمفاهيم التربية الإيمانية من وصايا الرسول الإس إرشاداته في تلقين

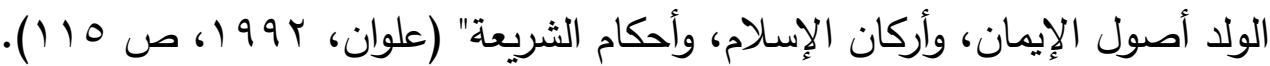

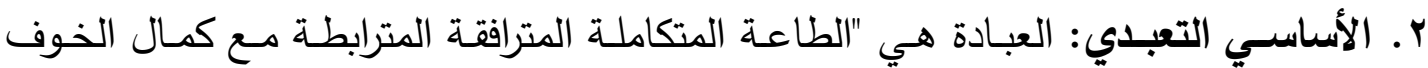
وكمال الحب، والطاعة منبثقة عن قناعة عقلية بأن الله تعالى خالق كل شيء وقادر على على لهي كل شيء، يدخل الجنة الصالحين من عباده ويدخل النار الأثقياء والكافرين من خلقهـ ...

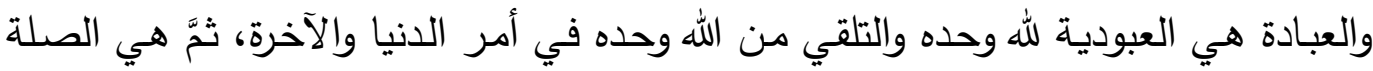

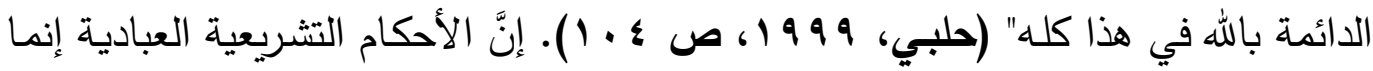

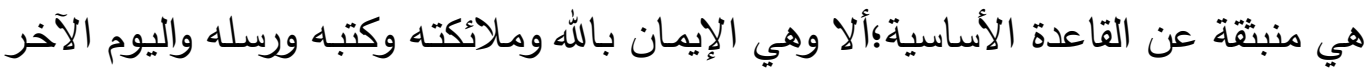

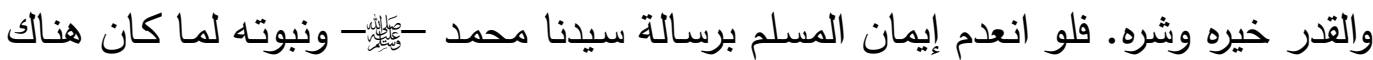

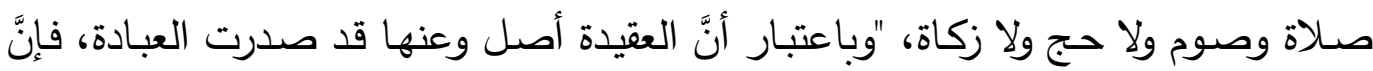

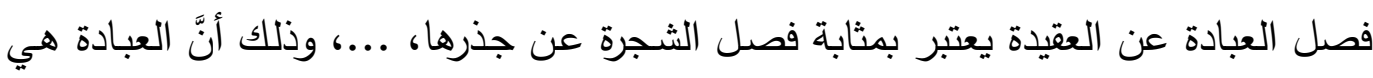

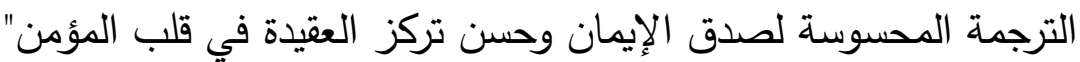

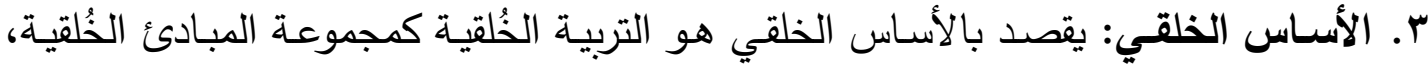
والفضائل السلوكية والوجدانية التي يجب أن يتلقنها الطفل ويكتسبها ويعتاد عليها منذ تمييزه وتعقله إلى أن يصبح مكلفاً إلى أن يتدرج شاباً إلى أن يخوض خضئ خضمّ الحياة. 
ع. الأسساس البدني: تتمية الجسد وتوجيه نموه باتجاه تحصيل الصحة والقوة فتزداد مقاومته

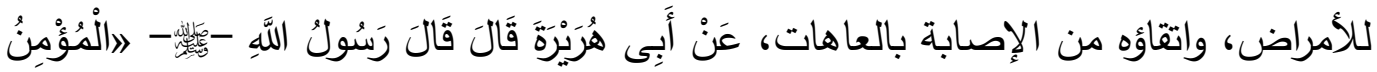

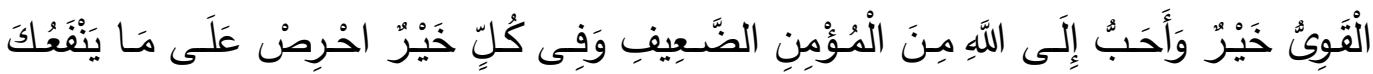



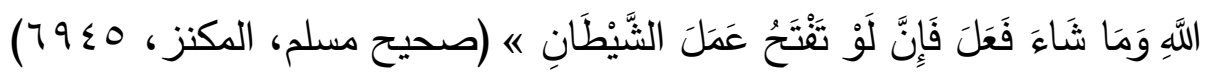

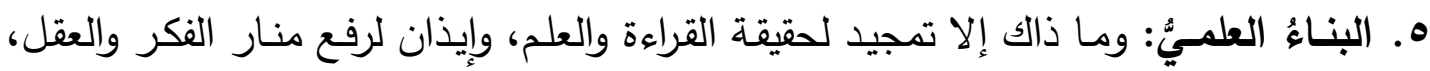

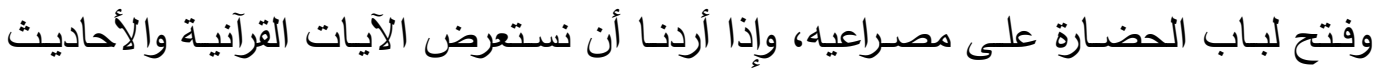
النبوية التي تحض على العلم، وترفع من منزلة العلماء، نجدها كثيرة ومستقيضة يستظهرها

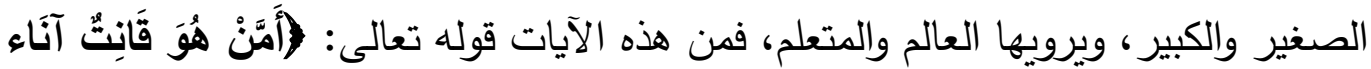

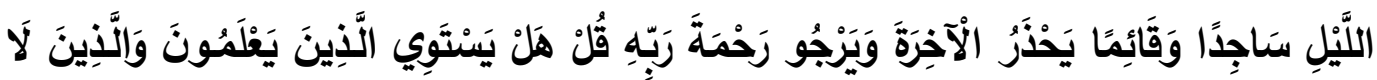

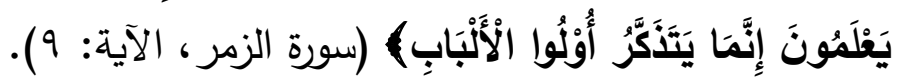

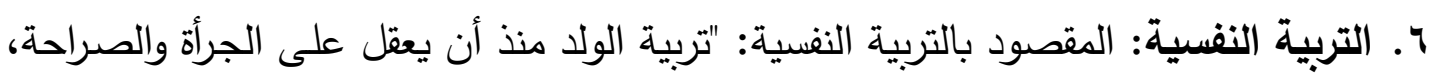

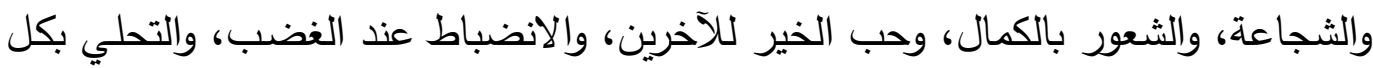
الفضـائل النفسية والخلقيـة على الإطلاق" والهدف من هذه التربيـة تكوين شخصية الولد

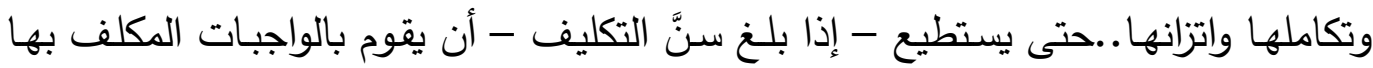

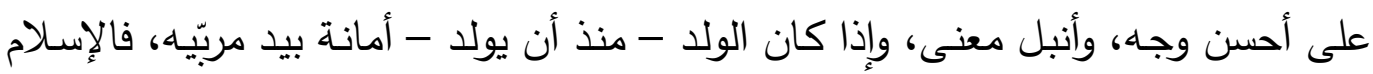
يأمرهم ويحتم عليهم أن يغرسوا فيه منذ أن يفتح عينيه أصول الصحة الصحة النفسية التي تؤهله

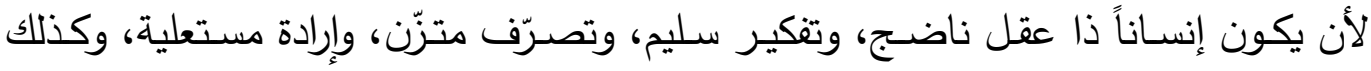
عليهم أن يحرروا الولد من كل العوامل التي تغض من كرامته واعتباره، وتحطم من كيانه وشخصيته، والتي تجعله ينظر إلى الحياة نظرة حقد وكراهية وتثاؤم.

\section{المطلب الثالث أساليب التربية في عصر صدر الإسلام:}

1. التربية بالقصة: إن القصة أمر محبب للناس، وتترك أثرها في النفوس، ومن هنا جاءت التهات

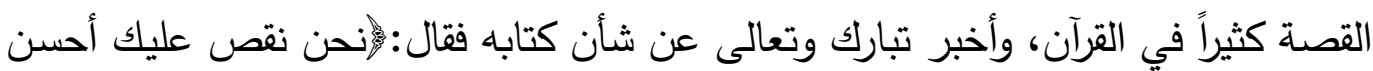

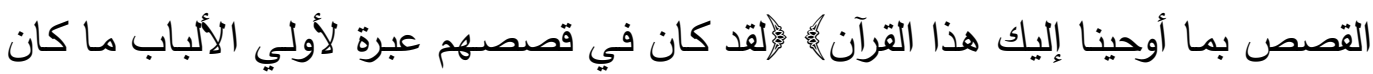

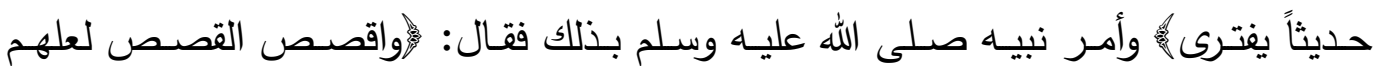

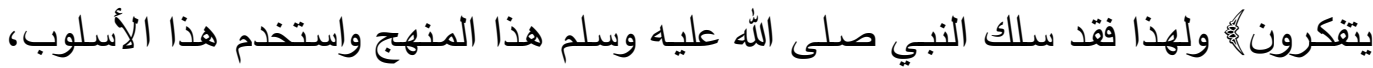


وحفظت لنا السنة النبوية العديد من المواقف التي يحكي فيها النبي صلى الله عليه وسلم قصة من القصص، فمن ذلك: قصة الثلاثة الذين آواهم المبيت إلى الغار، وقصة الذي قتل مائة نفس، وقصة الأعمى والأبرص والأقرع، وقصة أصحاب الصحاب الأخدود.

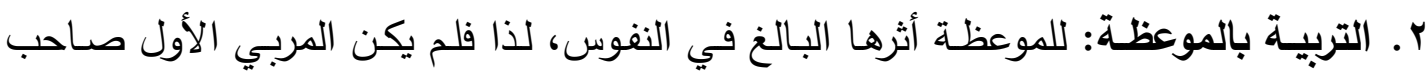

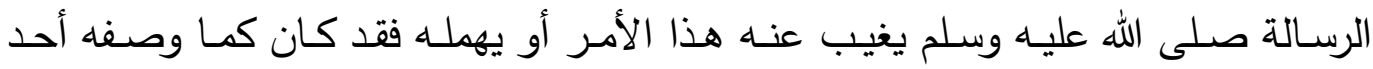
أصحابه وهو ابن مسعود كرضي الله عنه-::اكان رسول الله صلى الله عليه وسلم يتخولنا

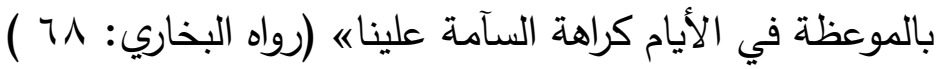

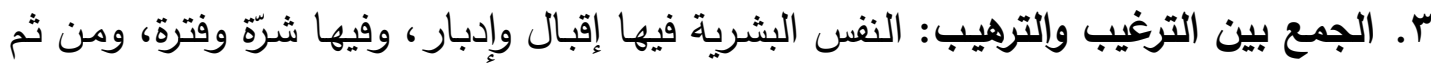

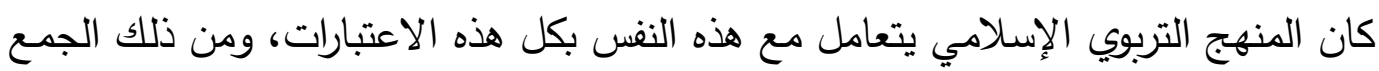

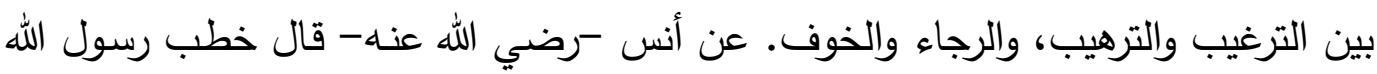


ولبكيتم كثيراً قال: فغطى أصحاب رسول الله صلى الله عليه وسلم وجوههم لهم خنين (رواه

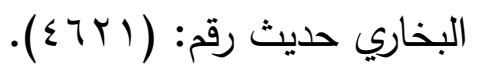

ء. استخدام الحوار وإلنقاش: وخير مثال على ذلك موقفه صلى الله عليه وسلم مع الأنصار في غزوة حنين بعد قسمته للغنائم، فقد أعطى صلى الله عليه وسلم المؤلفة قلوبهم وترك الأنصار ، فبلغه أنهم وجدوا في أنفسهم، فدعاهم صلى الله عليه وسلم، وكان بينهم وبينه هذا

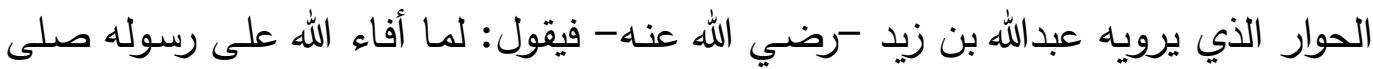
الله عليه وسلم يوم حنين قسم في الناس في المؤلفة قلوبهم ولم يعط الأنصار شيئا، فكانهم وجدوا إذ لم يصبهم ما أصاب الناس، فخطبهم فقال: "يا معشر الأنصار ، ألم أجدكم ضـلالا فهداكم الله بي؟ وكنتم متفرقين فألفكم الله بي؟ وعالة فأغناكم الله بي؟" كلما قال شيئاً قالوا: الله ورسوله أمن، قال: «ما يمنعكم أن تجيبوا رسول الله صلى الله عليه وسلم ؟" قال كلما


الناس بالثـاة والبعير وتذهبون بالنبي صلى الله عليه وسلم إلى رحالكم؟ لولا الهجرة لكنت امرأ من الأنصار ، ولو سلك الناس واديا وشعبا لسلكت وادي الأنصسار وشعبها، الأنصار شعار والناس دثار، إنكم ستلقون بعدي أثرة فاصبروا حتى تلقوني على الحوض" (رواه 
البخاري، حديث رقم: · بـاء) فقي هذا الموقف استخدم النبي صلى الله عليه وسلم الحوار



$$
\text { شئتم لقلتم ولصدقتم وصُدقتم ...). }
$$

ه. استخدام التوجيه غير المباشر: ويتمثل التوجيه غير المباشر في أمور منها: كونه صلى وصى الله عليه وسلم يقول مابال أقوام، دون أن يخصص أحداً بعينه، ومن ذلك قوله في قصدية بريرة فعن عائشـة كرضي الله عنها- فقالت أتتها بريرة تسألها في كتابتها فقالت إن شئت أعطيت أهلك ويكون الولاء لي فلما جاء رسول الله صلى اللهم عليه وسلم ذكرته ذلك قال النبي صلى اللهم عليه وسلم ابتاعيها فأعتقيها فإنما الولاء لمن أعتق ثم قام رسول الله صلى لهى اللهم عليه وسلم على المنبر فقال ما بال أقوام يشترطون شروطا ليست في كتاب الله من اشترط شرطا ليس في كتاب الله فليس لله وإن اشترط مائة شرط (رواه البخاري، حديث رقم: Pro و Y ومسلم ) وحديث أنس -رضي الله عنه- أن نفرا من أصحاب النبي صلى الله عليه

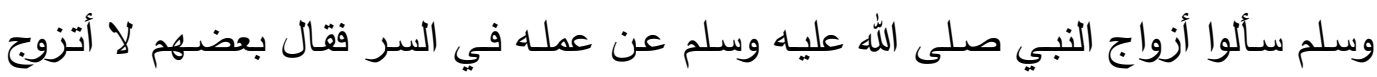

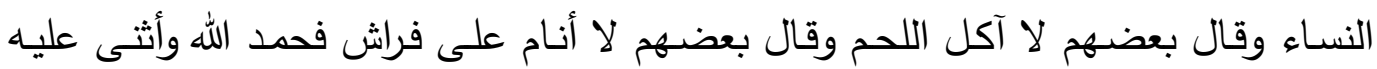

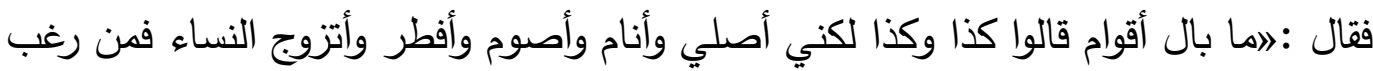
عن سنتي فليس منيه (رواه البخاري، حديث رقم: (1) بـ (1). 4. استثمار المواقف والفرص: إن المواقف تستثير مشاعر جياشة في النفس، فحين يستثر هذا الموقف يقع التعليم موقعه المناسب، ويبقى الحدث وما صاحبه من توجيه وتعليم صورة منقوشة في الذاكرة، تستعصي على النسيان. والمواقف متتوعة فقد يكون الموقف موقف حزن وخوف فيستخدم في الوعظ، كما في وعظه صلى الله عليه وسلم أصحابه عند القبر .

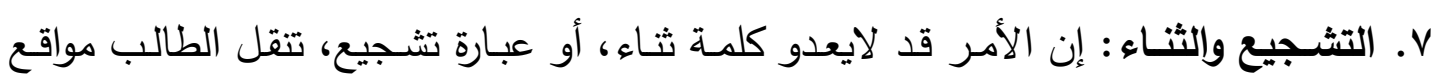
ومراتب في سلم الحرص والاجتهاد. والنفس أياً كان شأنها تميل إلى الرغبة في الثعور بالإنجاز • ويدفعها ثناء الناس -المنضبط- خطوات أكثر والتشجيع والثناء حث للآخرين، ودعوة غير مباشرة لهم لأن يسلكوا هذا الرجل الذي توجه الثناء لله. 


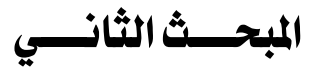 \\ مجالات التربية الإسلامية في عصر صدر الإسلام}

تُعدُ فترةُُ صدرِ الإسلامِ من أفضلِ فتراتِ التاريخِ الإسـلامي، ولها في نفوسِِ المسلمينَ

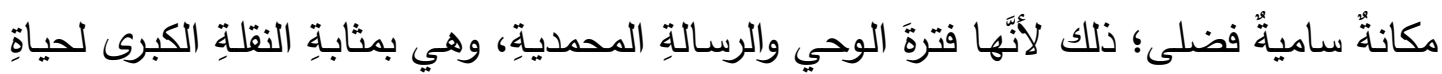

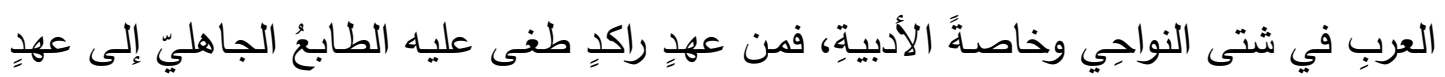

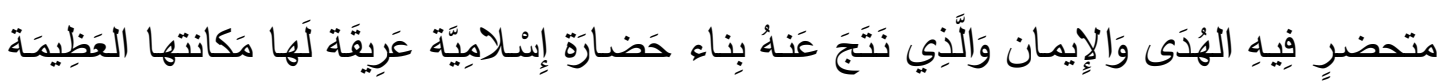

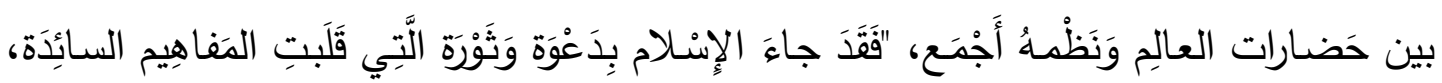

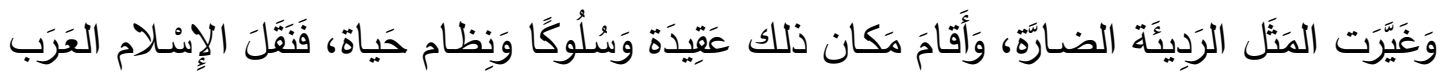

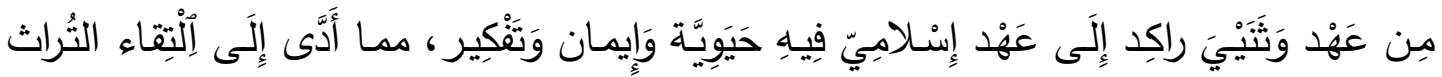

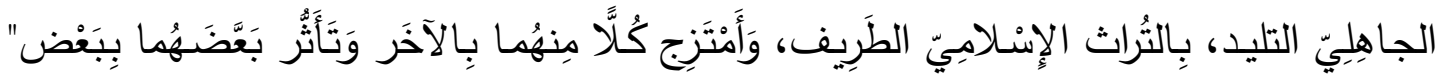

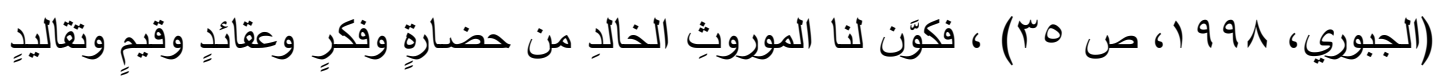
راسخةٍ متينةٍ في الشخصِ السلِّ.

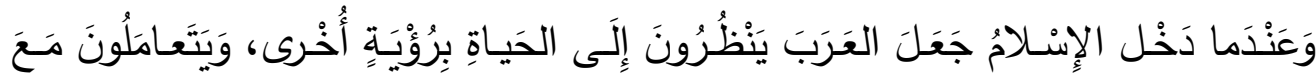

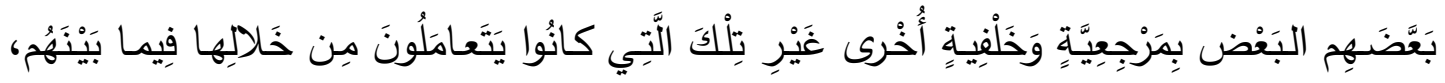

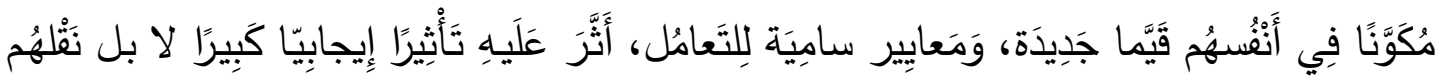

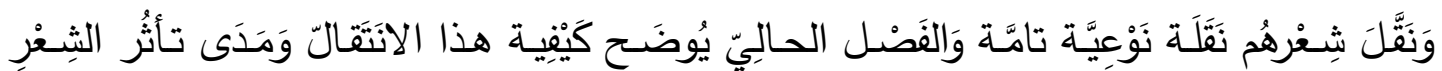

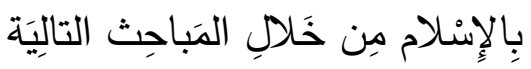
وكانت بعثة محمّد صلّى الله عليه وسلّم نعمةًَ من الله تعالى أهدت إلينا قواعد المعرفة

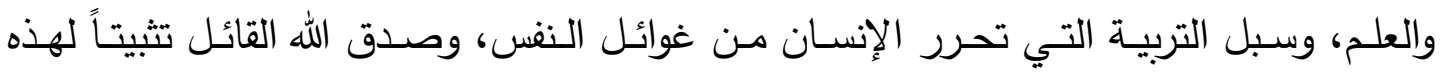

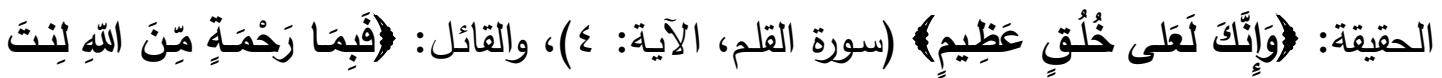

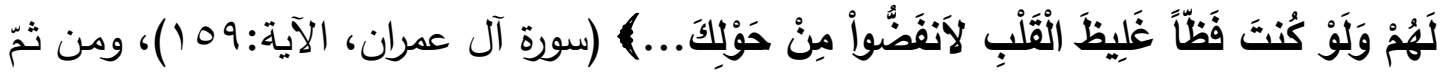
جعله الله بسبب هذه المزيّة قدوةً للناس، وجعل منها حاملاً على محبّتهم لله وتأستيّهم به. فقال

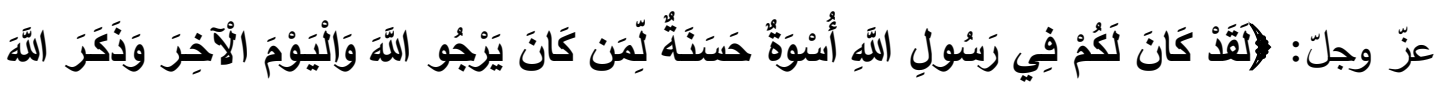
كَثِيراً ) (سورةالأحزاب، الآية: (r). 


\section{المطلب الاول: التربية العةلية في عصر صدر الإسلام:}

التربية العقلية تعتمد على رعاية ابنه من الناحية العقلية، ويلاحظ الصحة العقلية في الولد،

فكل ما يؤثر على عقل الولد وذاكرته، واتزانه؛ فعليه أن يبعده عنه، وأن ينهاه عنه، ويبيّن له خطره

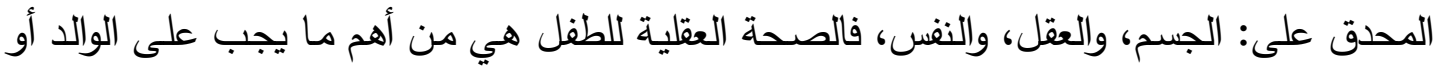

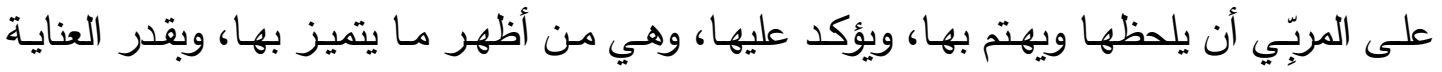
والهلاحظة والاهتمام يتحقق للولد الوقاروالتعقل والاتزان (علوان، ب99 19، ص بـ ـ (). وعلى والد

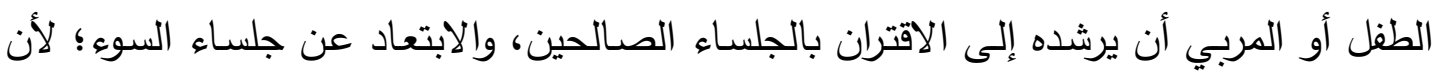

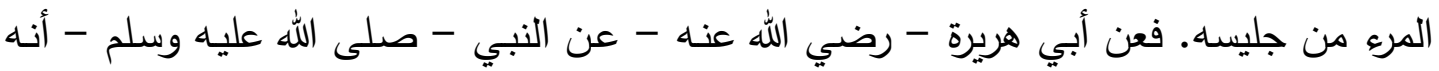

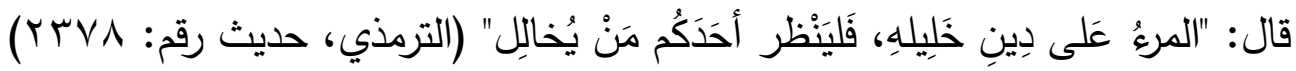
وتتجلى التربية العقلية في عصر صدر الإسلام في المواقف التالية:

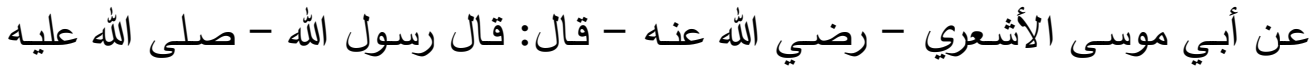

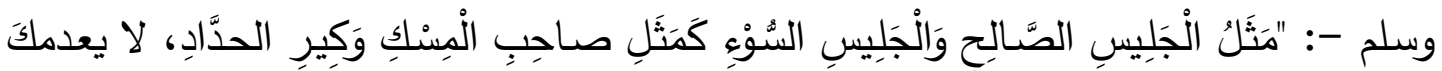



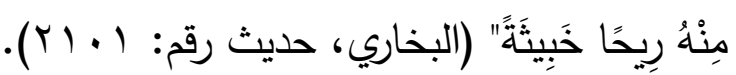
ها هو أبو بكر الصديق رضي الله عنه يقول: " أي سماء تظلني، وأي أرض تقلني إذا لها أنا قلت في كتاب الله بغير علم " (ابن ماجة، حديث رقم: (I) لو ). لقد كان أبو بكرالصديق أحسن مثال للمؤمنين الذين يقرؤون القرآن بالتدبر والفهم. فكان

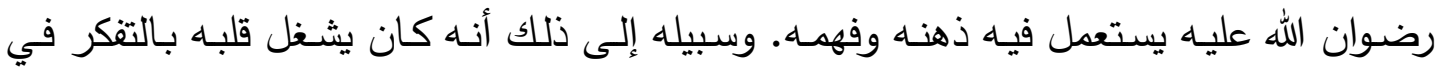

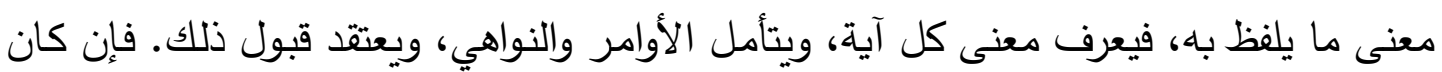

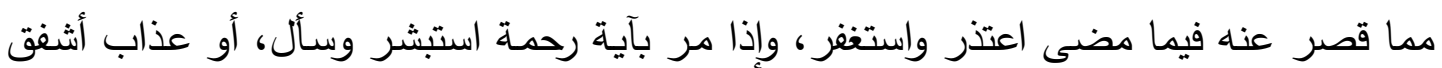
وتعوذ، أو تنزيه نزه وعظم، أو دعاء تضرع وطلب. وذلك اقتداء بالنبي صلى الله عليه وسلم.

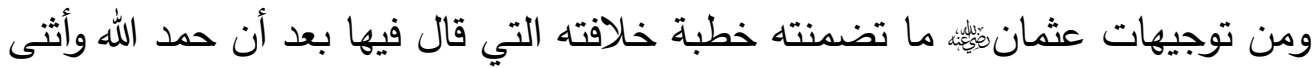

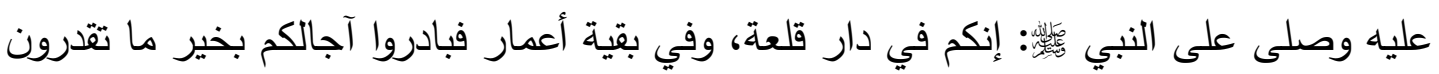

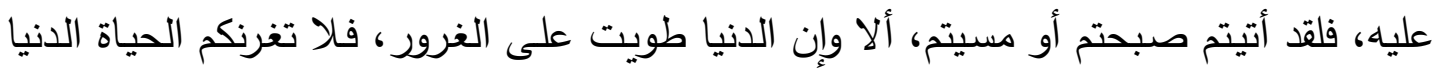

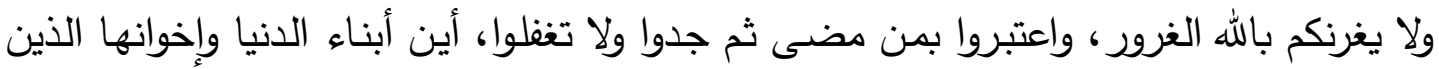




ولقد كان المعنى الذي يدور حوله توجيه الخليفة الثالث في هذه الخطبة هو الحض على الإقبال على الله والزهد في الدنيا، وهذا هو المناسب لخطبته في ذلك الوقت الذي ألته ألقى فيه

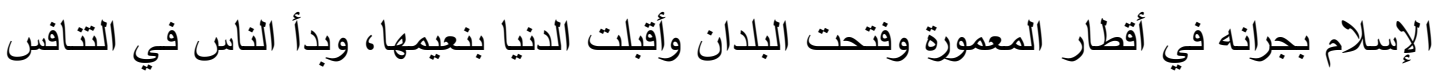

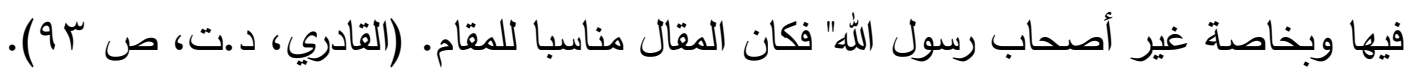

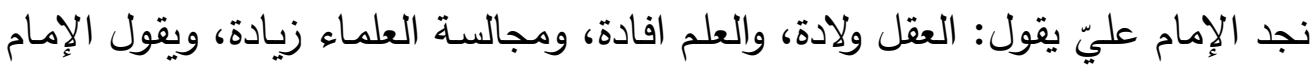

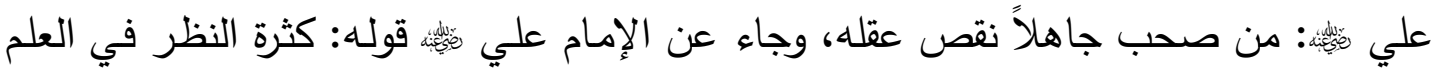

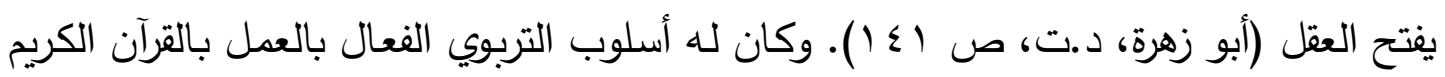

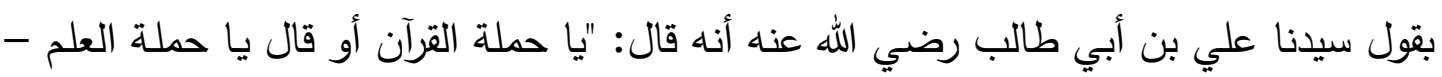

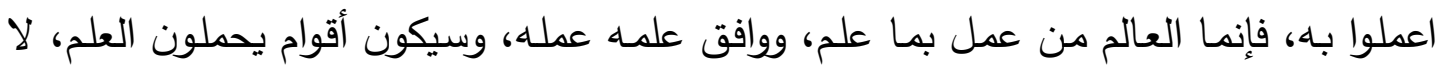

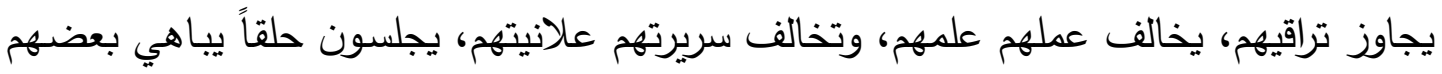

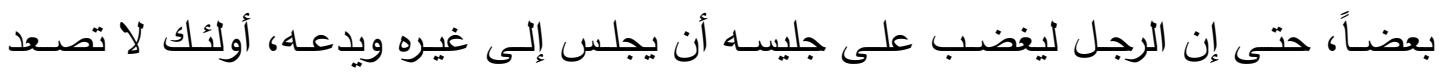

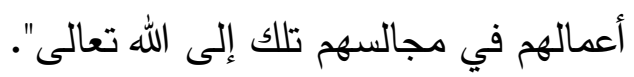

\section{المطلب الثاني: التربيـــة العقديـيسة:}

تأتي التربية العقدية بترسيخ حب الله تعالى، والاستعانة به، ومراقبته، وبالإيمـان بالقضـاء

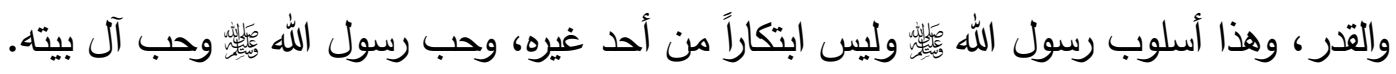

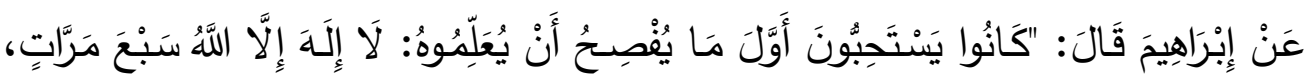

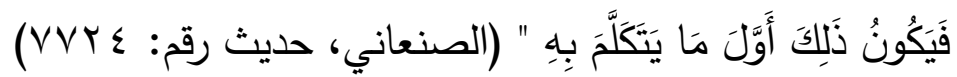

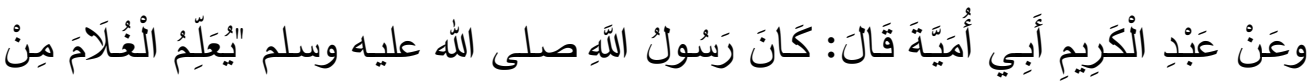

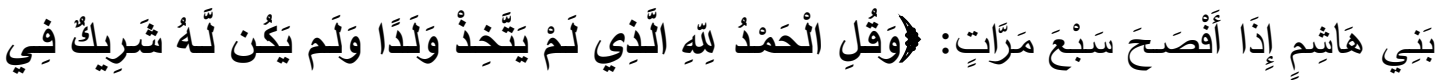

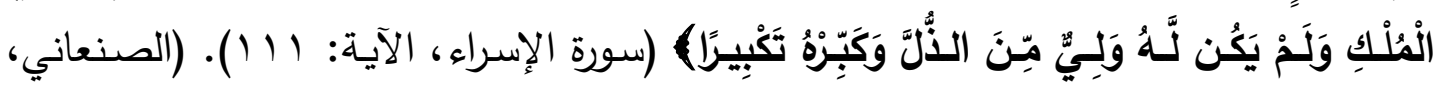
حديث رقم: VVYT).

قال ابن القيم: "فإذا كان وقت نطقهم فليلقنوا لا إله إلا الله محمد رسول الله

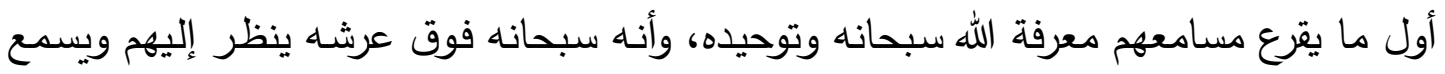

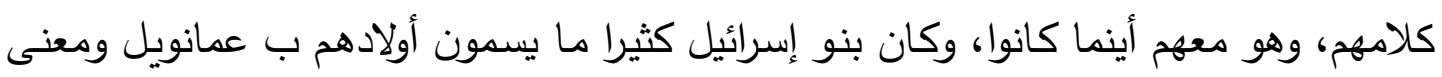

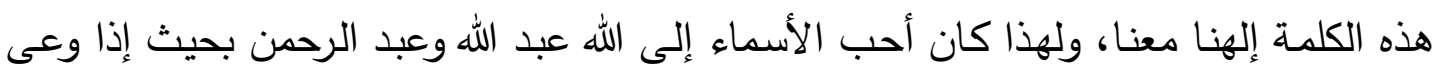




المطلب الثالث التربية العبادية والايمانية:

بناء العبادة يعدُّ مكملاً لبناء العقيدة، إذ العبادة تغذي العقيدة بروحها، كما أنها المنعكس الذي يعكس صورة العقيدة ويجِّمها، والطفل عندما يتوجه لنداء ربه، ويستجيب لأوامره فإنما هو يلبي غريزة فطريـة في نفسـ، فيشبعها ويرويها، فلابدَّ لكي يظل غرس العقيدة قويَّا في النفس،

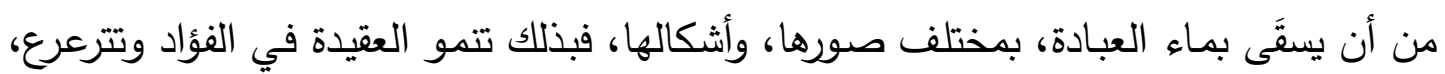
وتتبـت أمسام عواصف الحياة وزعازعها (البوطي، د.ت، ص • ع). وإن الله تعالى ليعجب من الولد الذي لا صبوة له، فَعَنْ عُعْبَةَ بْنِ عَامرِ، قَالَ: قَالَ رَسُولُ اللهِ لَيَسَتْ لَلَهُ صَبْبوةُة. وإن رسول الله

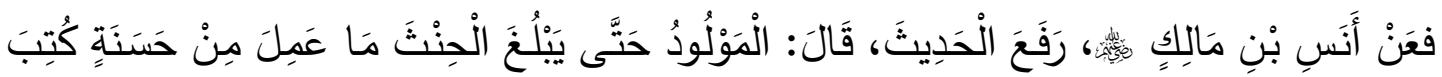

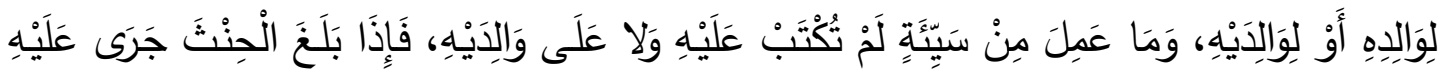

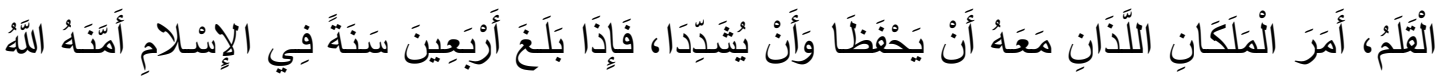

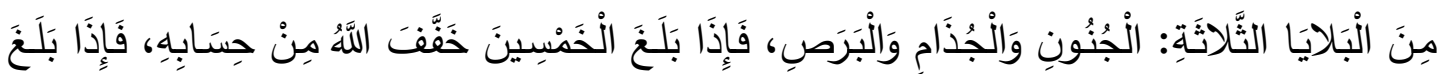

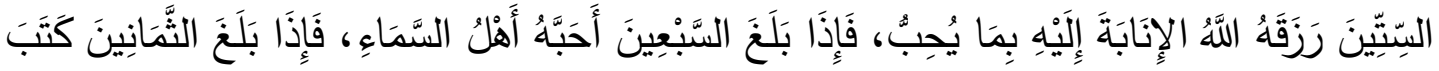

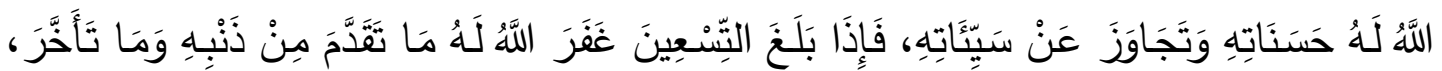

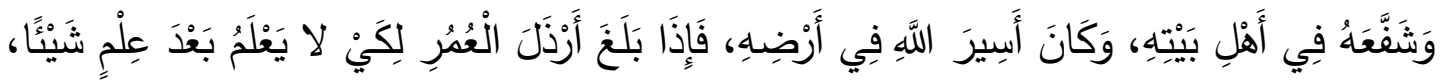

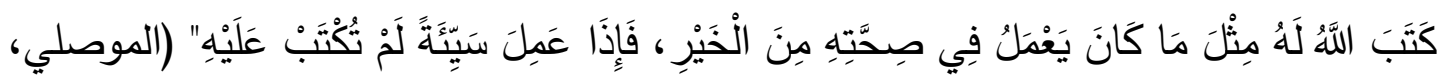
حديث رقم: بV^ كان ذا رقة وحساسية ولا يملك نفسه من البكاء عند تلاوة القرآن، قالت: (إنّ أبا بكر رجلٌ رقيقُ) وفي رواية (أَسِيفت) وفي روايةٍة: "كان أبو بكر رجلا بكّاءً؛ لا يملكُ عينيه إذا قرأ القرآن" (الباري، لئه جزء V، ص (T) (T).

وكان عثمان نِئه: دائماً يحث على الإجتهاد في العبادة، وقد كان من المجتهدين في العبادة، وقد روى من غير وجه أنه "صلى بالقرآن العظيم في ركعة واحدة عند الحجر الأسود

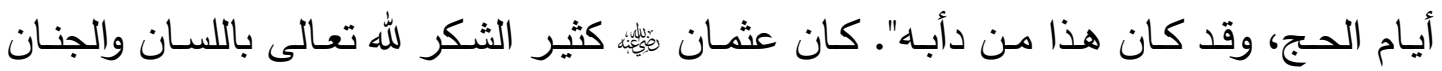
والأركان، دعى ذات يوم إلى قوم على ريبة، فانطلق ليأخذهم فتفرقوا قبل أن يبلغهم، فأعتق رقبة شكرا لله أن لا يكون جرى على يديه خزي مسلم (الهيتمي، جزه، ص VTr). 


\section{المطلب الرابع: التربية الاجتماعية:}

التربية الاجتماعية هي أن يكون الفرد متكفياً مع وسطه الاجتماعي، سواء مع الكبار ،

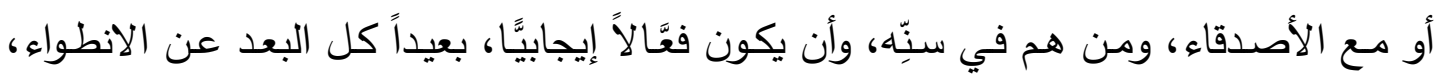

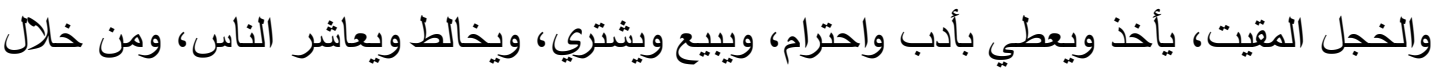

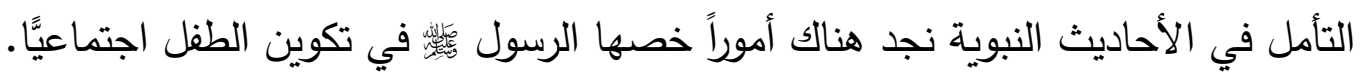

\section{الفرع الأول : اصطحاب الطفل لمجالس الكبار:}

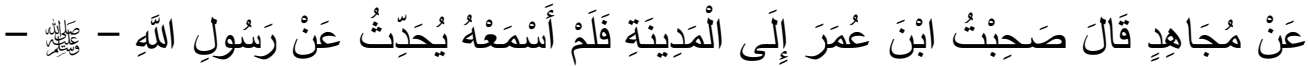



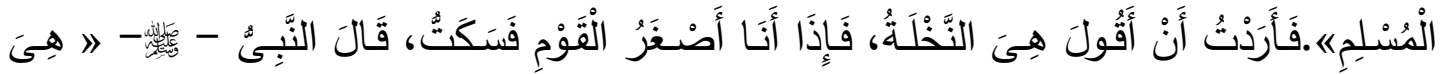

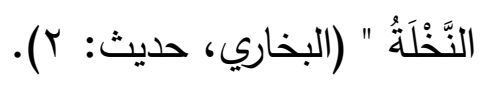

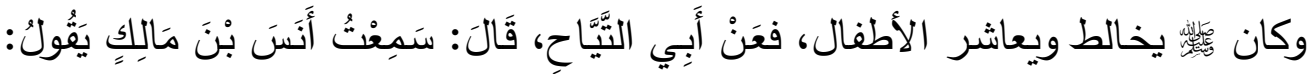
كَانَ رَسُولُ اللهِ

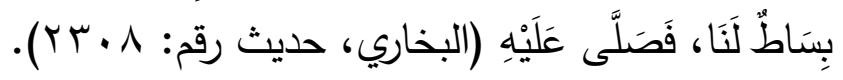

\section{الفرع الثاني: إرسال الطفل لقضاء الحاجات :}

وهذا عامل هام في نشوء الطفل اجتماعيا، إذ أن قضاء الحاجات المنزلية، أو لأحد

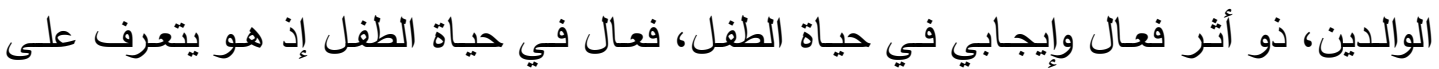

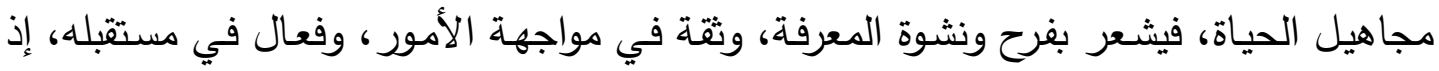
يكون قد اكتسب مهارة، وخبرة في طفولته التي تمكنه من متابعة حياته، بخطى ثابتة مركزة بدون خلل أو اضطراب.

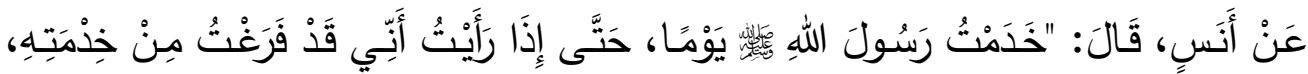
قُلْتُ: يَتِيلُ رَسُولُ اللهِ رَسَولُ اللهَه

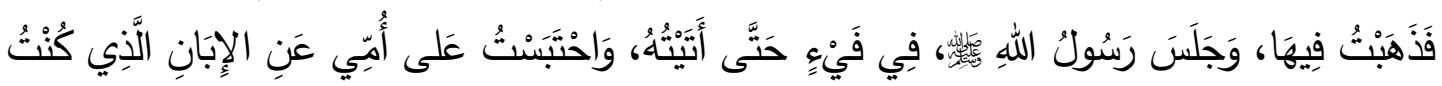

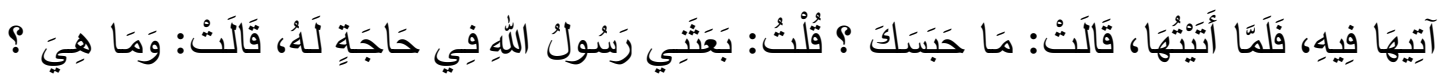

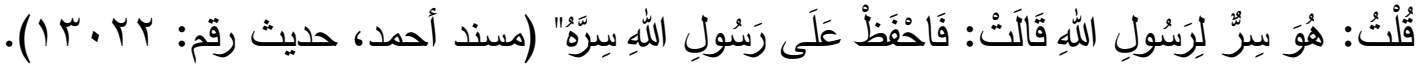




\section{الفرع الثالث تعويد الطفل سنَّة السلام:}

السلام هو التحية الإسـامية بين المسلمين، والطفل يتعرض للقاء الناس على اختلاف

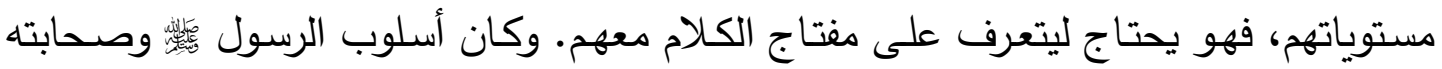
اسلوبًا لطيفا في غرس سنَّة السلام في نفس الطفل، وهو بدء الكبير بالسلام على الأطفال، حتى

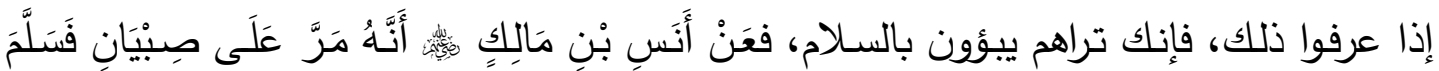
عَلَيْهِهْ وَقَالَ كَانَ النَّبَُّ

\section{الفرع الرابع أهمية الوحلدة الاجتماعية :}

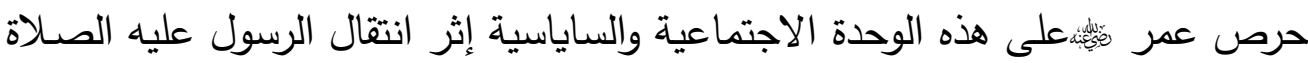
والسـلام إلى الرفيق الأعلى وفي اجتماع السقيفة رد كل الخلافات حتى أجمع الناس على أبي بكر رضي الله عنه خليفة للمسلمين.

\section{الفرع الخامس الرحمة والتآخي:}

ومنـه قول عمر بن الخطاب رضـي الله عنـه "لا يُرحم من لا يَرحم، ولا يُغفر لمـن لا

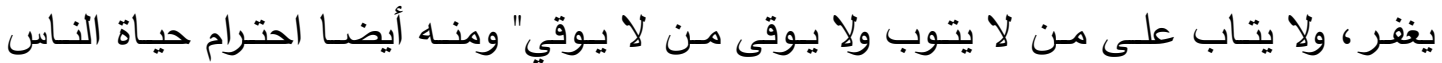
وأعراضهم وأماناتهم وإشباع حاجاتهم حيث قال "لا يعجبنكم من الرجل طنطنته ولكن إذا أدى

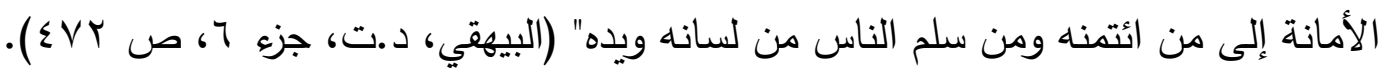
وكان لعثمان هيّئفي ذلك مواقف ومآثر لا تزال غرة في جبين التاريخ الإسـلامي؛ فلا يخفى لا أحد ما قام به في غزوة تبوك، وشراؤه لبئر رومة وتصدقه به على المسلمين، وتوسيعه للمسجد النبوي في عهد النبي وكان هيثئن يعتق كل جمعة رقبـة في سبيل الله منذ أسلم، فجميع ما أعتقه ألفان وأربعمائة رقبـة تقريبا. (الهتيمي، د. ت، ص YTV). لقد كان سخاء عثمان وجوده صفة أصلية في شخصيته الفذة ، فقد وظف أمواله في خدمة دين الله فلم يبخل في تأسيس الدولة الإسـلامية والجهاد في سبيل الله تعالى، وخدمة المجتمع ابتغاء رضوان الله تعالى.

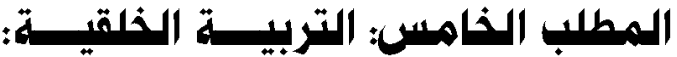

كما يسـى الإنسـان في سبيل إحياء مواهبـه الفكريـة، وإدرالك الحقائق العلميـة، ويحرز تقدما جديداً في كل يوم، كذلك عليه أن يسعى في سبيل تزكية نفسه وتطهيرها بالفضائل الخلقية 
قال الإمام العظيم: لو كنا لا نرجو جنة ولا نخشى ناراً ولا ثواباً ولا عقاباً، لكان ينبغي لنا أن

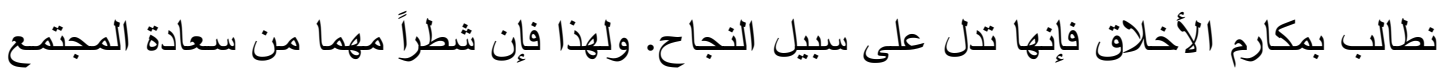

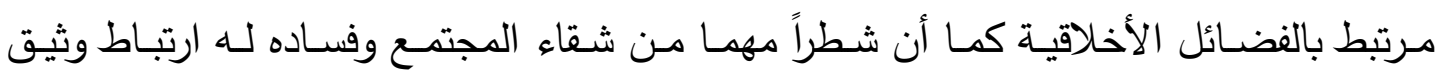
بالانحطاط الأخلاقي يقول الإمام: رُب عزيز أذله خلقه وذليل أعزه خلقه.

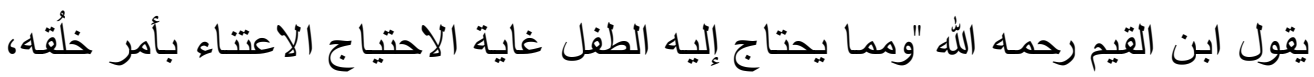

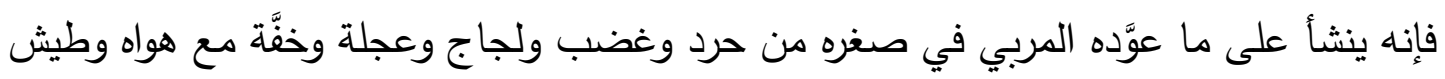

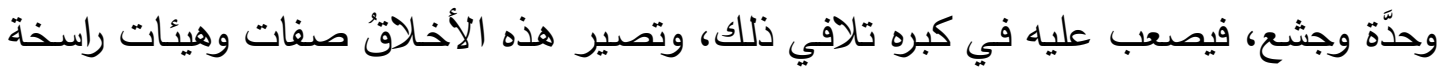

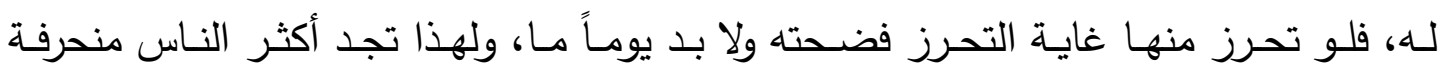


× الفرع الأول الحياء: خطب الصديق في الناس يوماً فقال: "أيها الناس استحيوا من الله فوالله

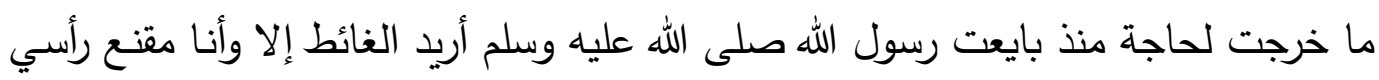
حياء من الله" الفرع الثاني التواضع: فقد روى الثـاذكوني: قال: "أخبرنا جعفر بن سليمان الضبيع قال:

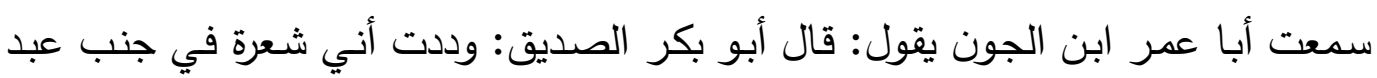

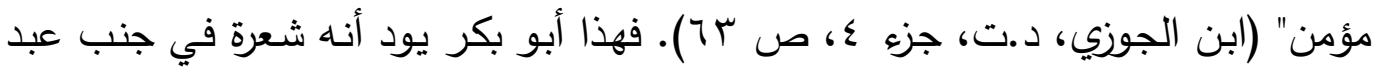
مؤمن وعمر يود أنه شعرة في صدر أبي بكر .

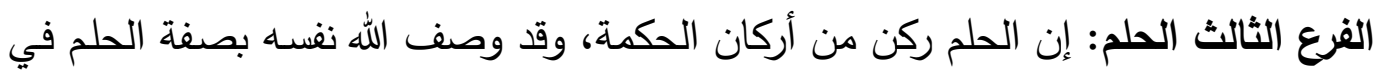

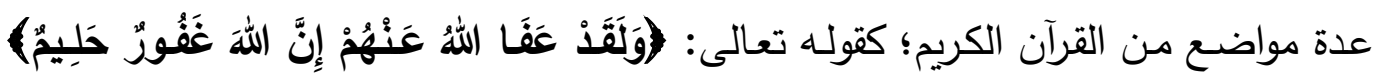

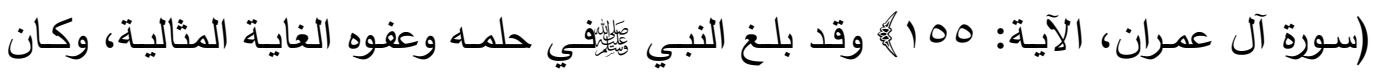

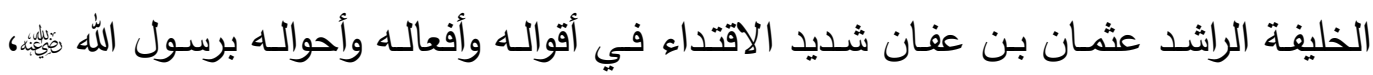

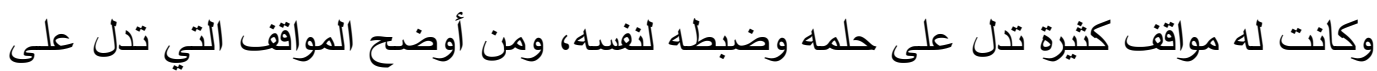

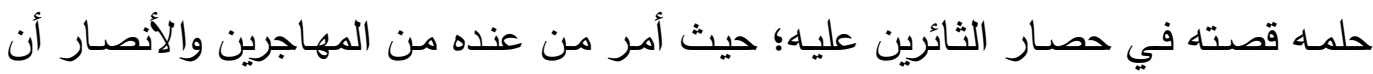
ينصرفوا إلى منازلهم ويدعوه وكانوا قادرين على منعه، وكان حلمه مبنيا على شوقه إلى لقاء





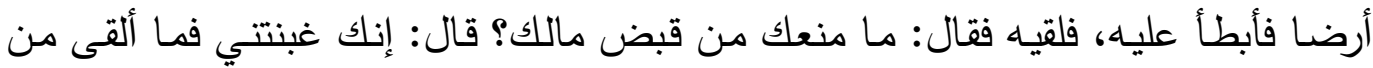


الناس أحدًا إلا وهو يلومني، فقال: أو ذلك يمنعك؟ قال: نعم، قال: فاختر بين أرضك ومالك، ثم قال: قال رسول الله

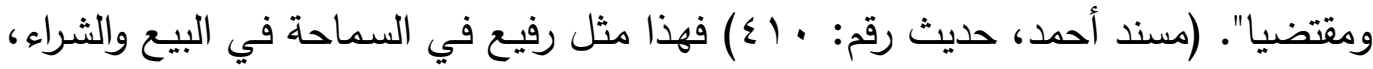
وهو يدل على ما جبل عليه عثمان هوّة من الكرم وعدم التعلق بالدنيا، فهو يستعبد الدنيا

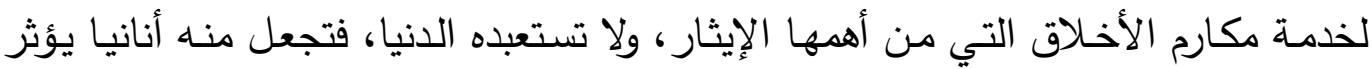
مصالحه الخاصة وإن أضر بالناس.

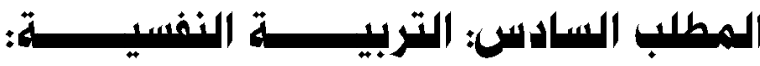

تثـكل العاطفـة مسـاحة واسـعة في نفس الطفـل الناشـئ، وهـي تكوّن نفسـهـ وتبنـي

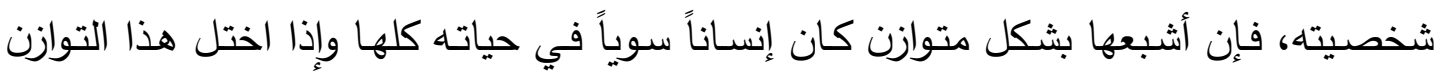

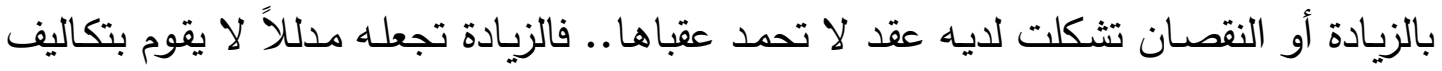

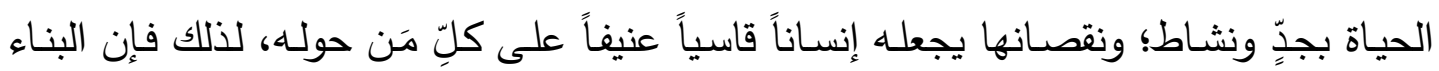
العاطفيَّ له أهية خاصة في بناء نفس الطفل وتكوينه.

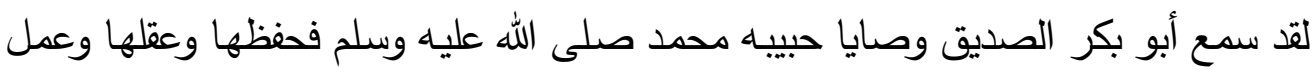
بها: "لا تحاسدوا، ولا تتاجشوا، ولا تباغضوا، ولا تدابروا، ولا يبع بعضكم على بلى بيع بعض، لهان، وكونوا

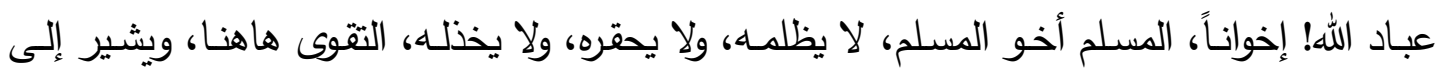

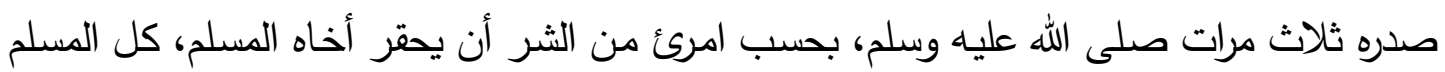

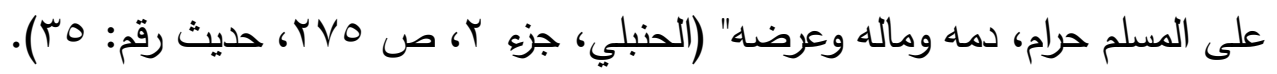

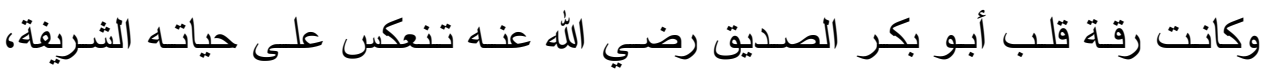

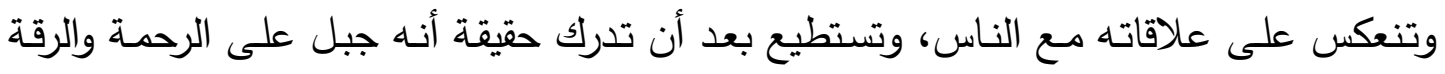

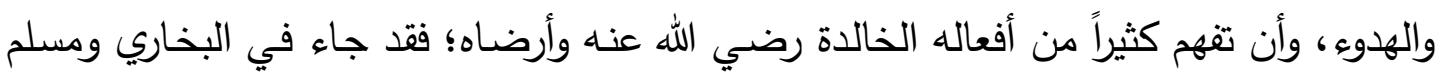

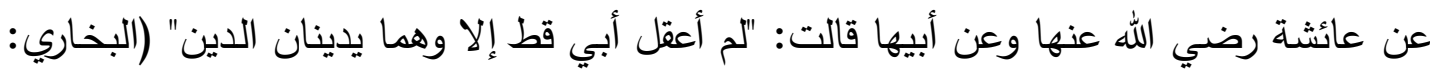

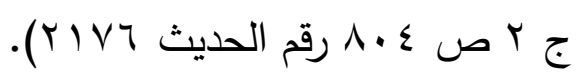

\section{ومن ملامح التربية النفسية في عصر صدر الإسلام ما يلي:}

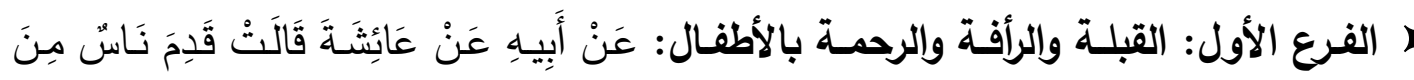

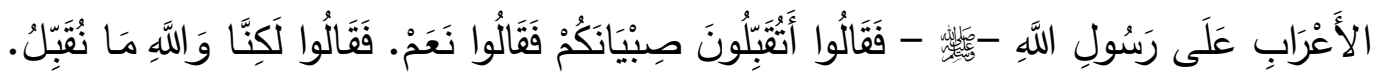

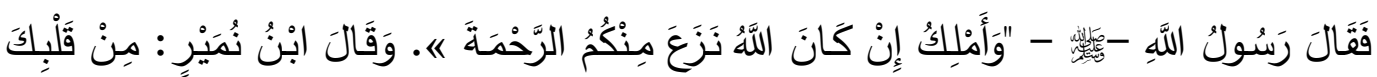

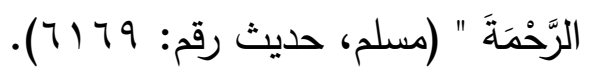




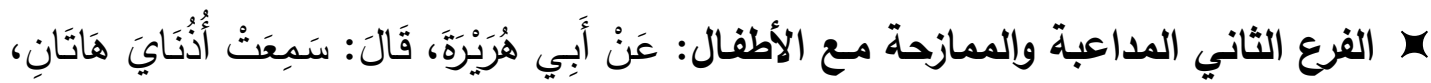
وَأَبْصَرَرَتْ عَيْنَايَ هَانَانِ رَسُولَ اللَّهِ قَََََيْ رَسُولِ اللَّهِ عَلَى صَذْرِ رَسُولِ اللَّهِ

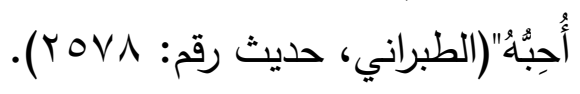

الفرع الثالث الهدايا والعطايا للأطفال: للهدايا أثر طيب في الثي النفس البشرية عامة، وفي نفوس الأطفال أكثر تأثيراً، أكبر وقعاً، وسنَّ رسول الله

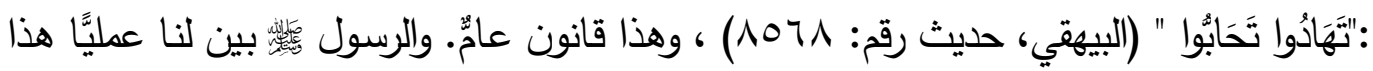





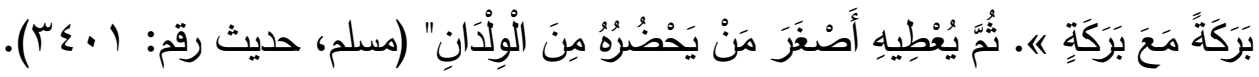

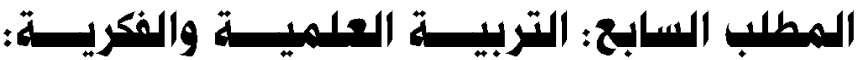


تناقلتها الأجيال كلها جيلاً بعد جيلٍ، فغدت تستتهض هم الآباء لحث أبنائهم على طلب العلم

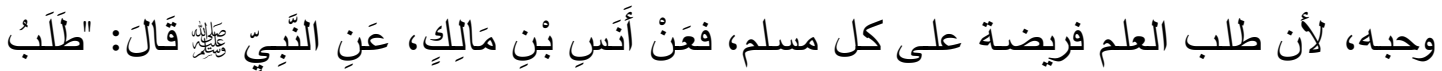

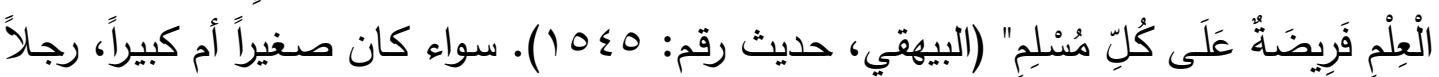

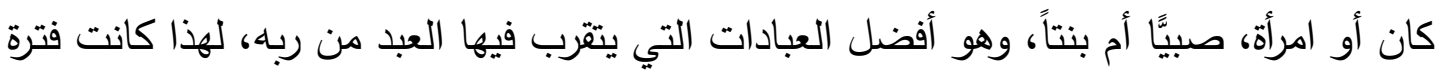
الطفولة أخصب فترة في البناء العلمي، والفكري للطفل.

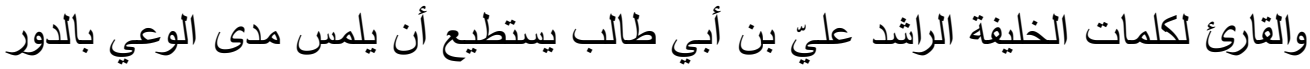

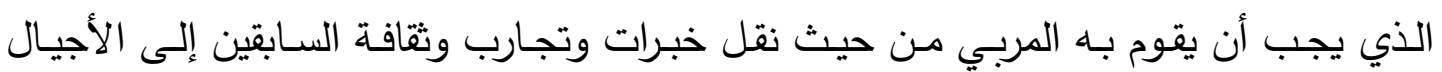

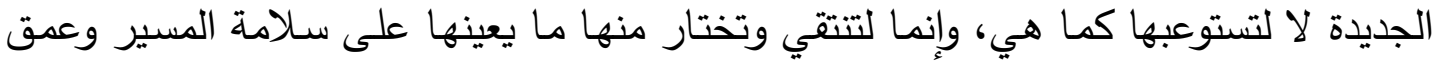

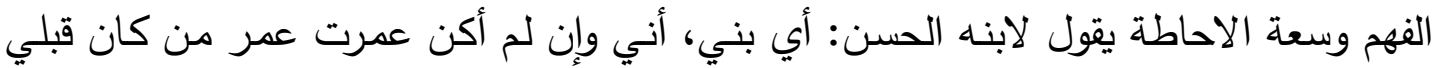



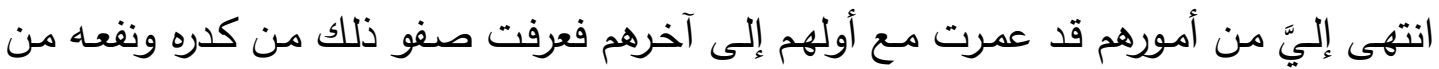

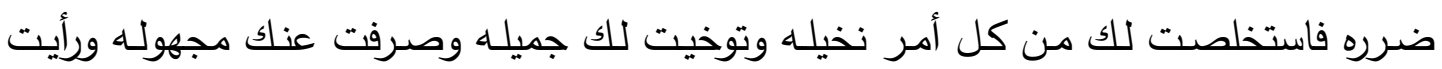

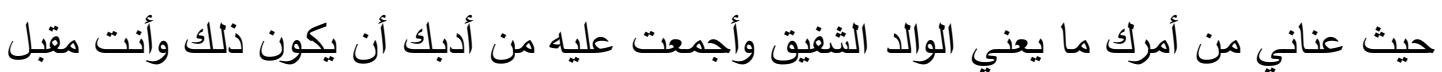

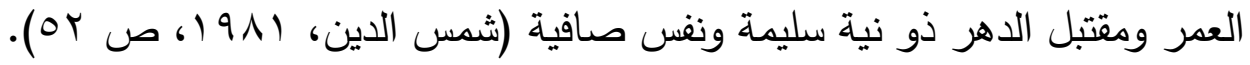






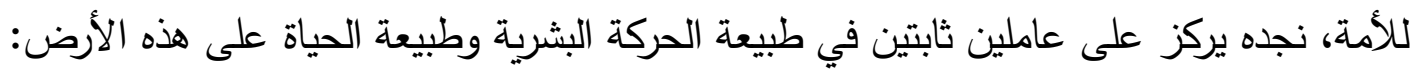

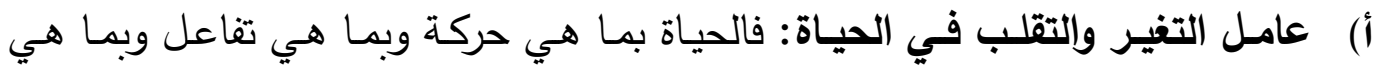

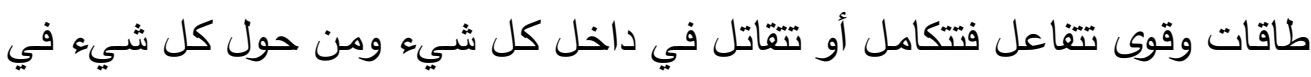

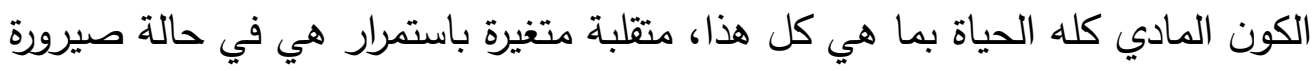
دائمة لا تستقر على حال ولا تثبت على وتيرة واحدة.

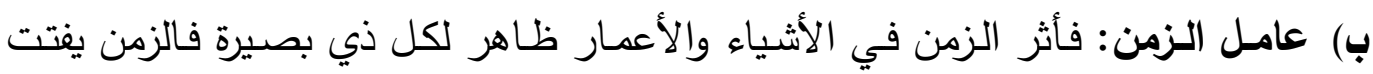

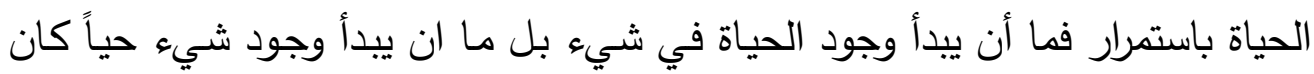

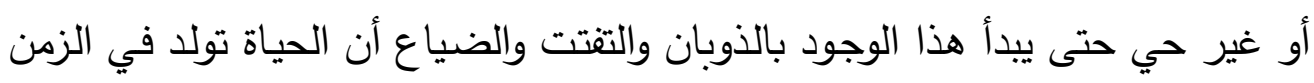

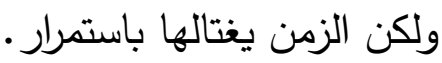
وهذان العاملان - التغير والزمن - لا يختصان بعالم الإنسان وحده، إنهما يعملان في

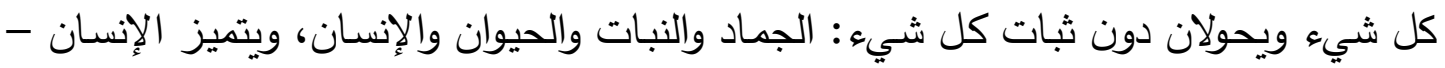

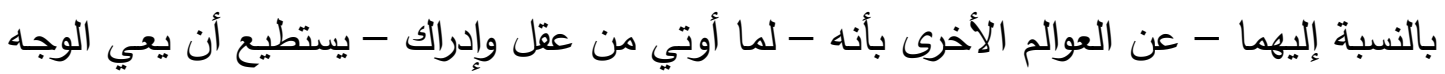

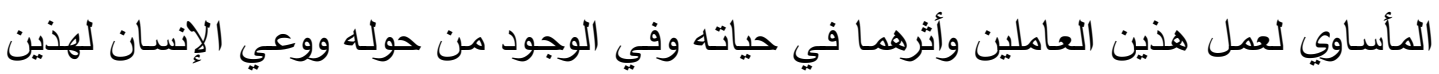
العاملين وأثرهما في الحياة والأثشياء يجعله قادراً على مواجهة الحياة ومباهجهاتها المؤقتئة.

\section{المطلب الثامن: التربية الصحية (الرعاية الصحية):}

إن الإسـلام قد اهتم بصـحة الإنسـان عامـة، وبصحة الطفل خاصـة، وقد حرص في

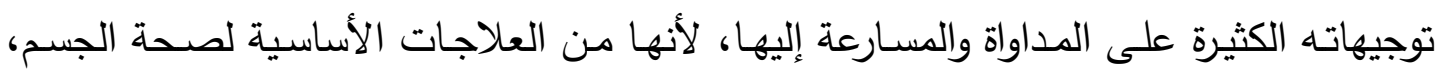



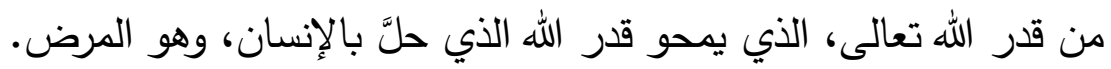
عَنْ جَابرِ ، عَنْ رَسُولِ اللهِ

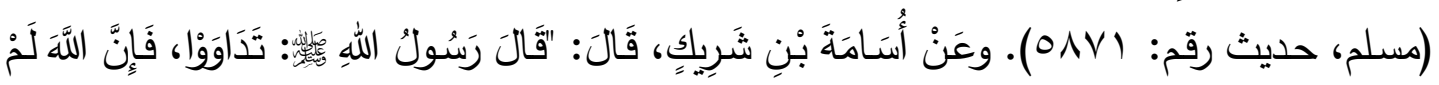

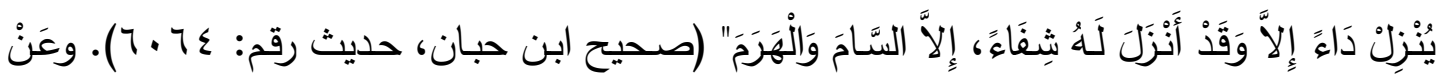



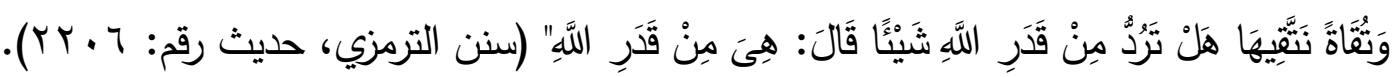

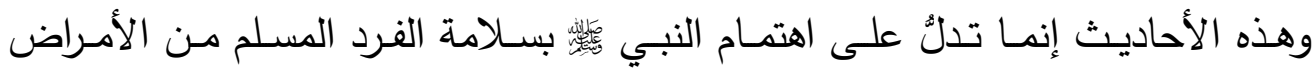

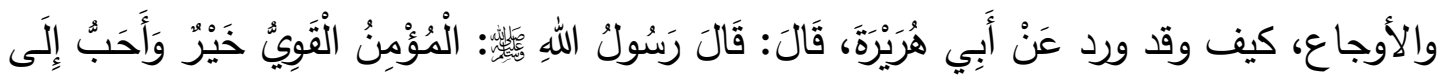




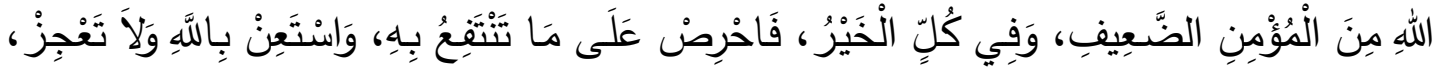

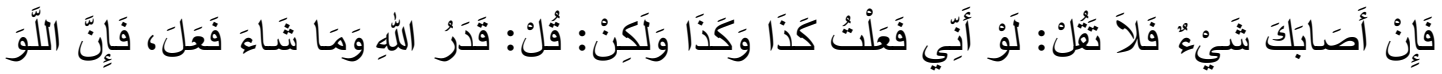

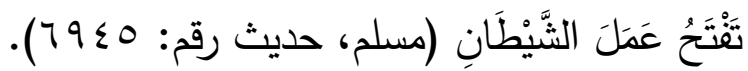

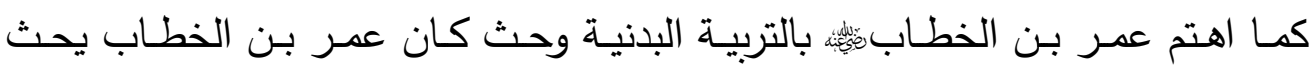
المسلمين على تعليم أولادهم التربية البدنية خاصة السباحة والفروسية والرماية حيث قال " علموا

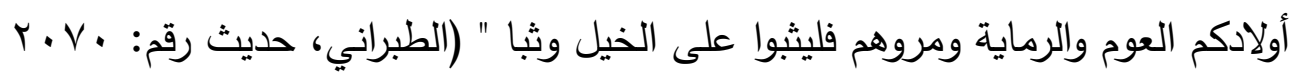

\section{المبحســــث الثالــــــ}

\section{التطبيقات التربوية المستنبطة من التربية في عصر صدر الإسلام}

في هذا المبحث تجيب الباحثة عن السؤال الثالث من البحث وهو ما التطبيقات التربوية

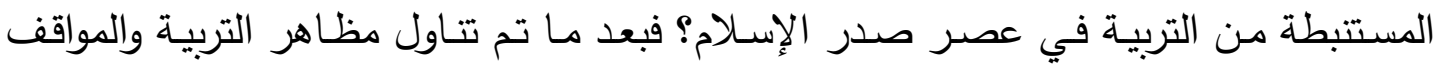

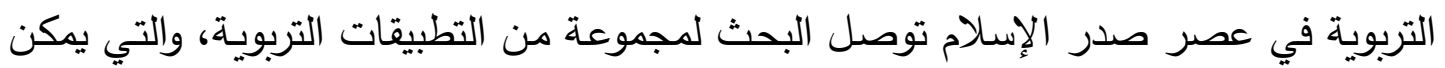

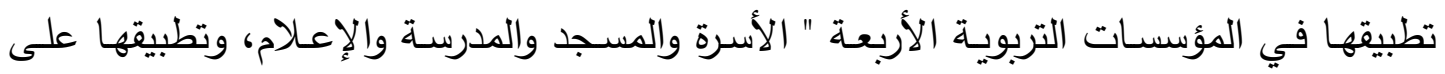

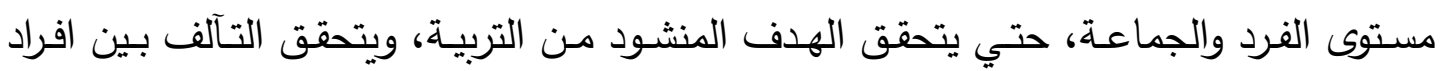

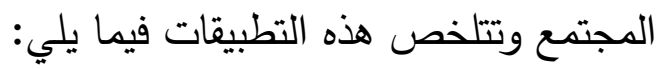
1- الحلم والأنـاة: فلابد على المربي أن يتحلى بالحلم والأناة في عند تربيته للأطفال فهذه

$$
\text { تصفات يحبها الله ورسوله. }
$$

r- الرفق واللين: فيجب على المربي التعامل مع الأبناء برفق ولين ولا يغلظ عليهم.

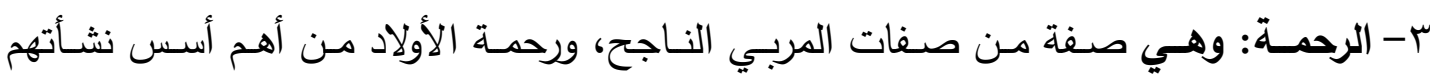

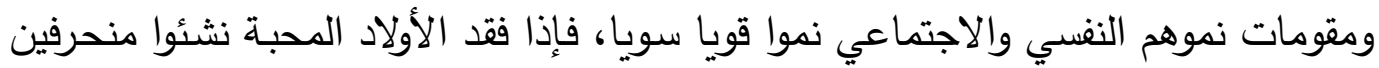

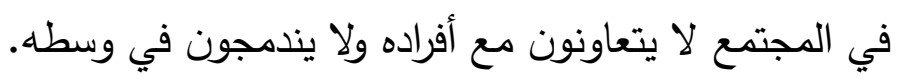

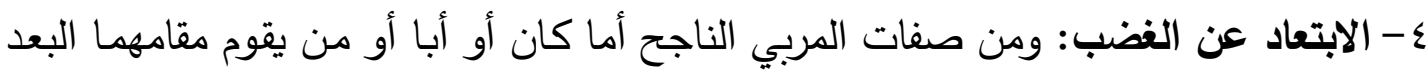

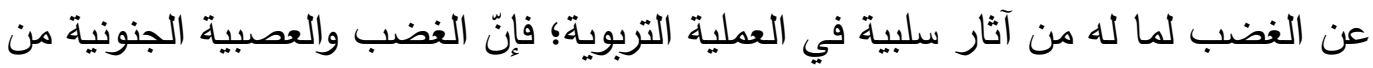
الصفات السلبية في العملية التربويـة ببل كذلك من الناحية الاجتماعية، فإذا ملك الإنسان غضبه، وكظم غيظه، كان ذلك فلاحا له ولاولاده ؛والعكس بالعكس.

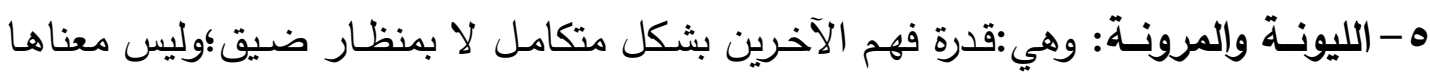

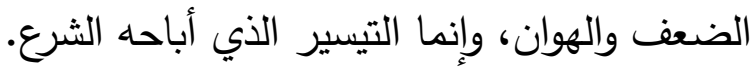


4- الاعتدال والتوسط: إن التطرف صفة ذميمة في كل الأمور ؛لهذا نجد أن رسول الله ـ . يحب الاعتدال في أمور الدين، فما بالك في باقي الأمور الحياتية الأخرى، والتي أهمها

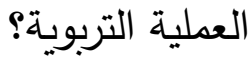
V- التحلي بالموعظة الحسنة: إن كثرة الكلام في كثير من الأحيان لا تؤتي أكلها ؛في حين نجد أن التخول بالموعظة الحسنة تؤتي أكلها كل حين بإذن ربها؛ فقد أخذ الصحابة رضي لي لئي الله عنهم هذه الصفة. 1- القدوة الحسنة وعلدم مخالفة الفعل للقول: فيجب على المربي أن قدوةً في سُلوكه، قدوةً في متلْبَسِه، قدوة في حديثه، قدوة في عبادته، قدوة في أخلاقه وآدابه، قدوة في حياته كلها. 9- الأمانة: وتشمل كل الأوامر والنواهي التي تضمنها الثرع في العبادات والمعاملات. • 1 - العدل: والعدل مطلوبّ في المعاملة والعقوبة والنفقة والملاعبة والثُبَل، ولا يجوز تمييز أحد الأولاد عن غيره. 11 - الحزم: وبـه قوام التربية، والحازم هو الذي يضع الأمور في مواضعها، فلا يتساهل في حال تستوجب الشدة ولا يتشدد في حال تستوجب اللين والرفق.

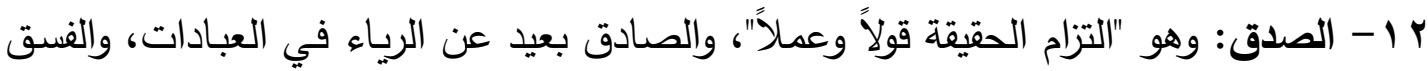
في المعاملات، وإخلاف الوعد وشهادة الزور ، وخيانة الأمانات.

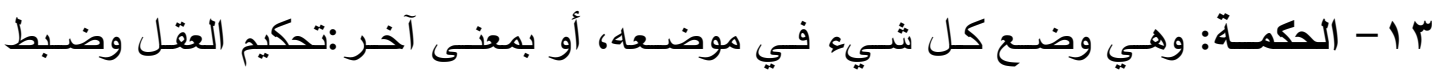

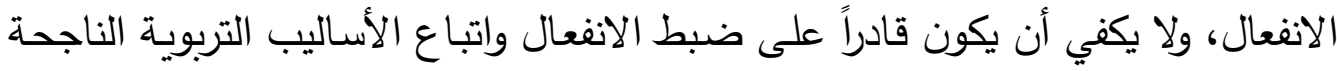

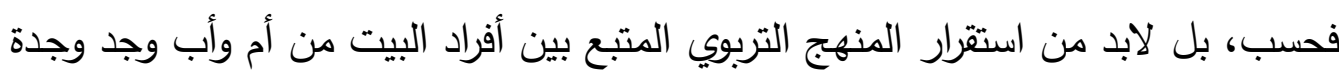

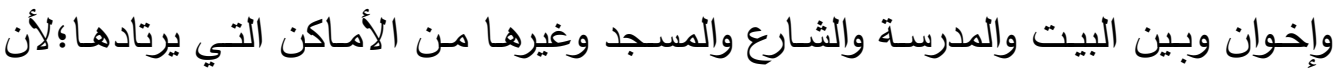
التتاقض سيعرض الطفل لمشكلات نفسية.

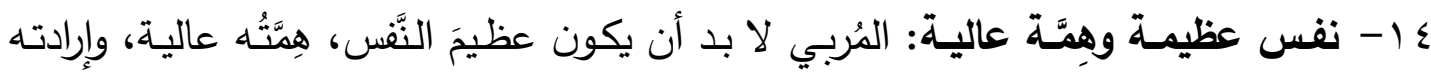

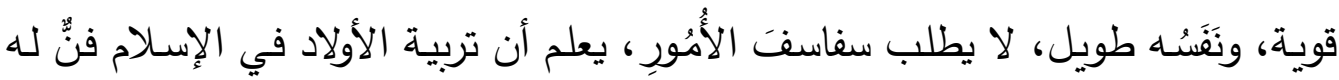



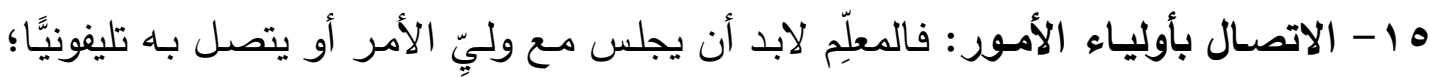

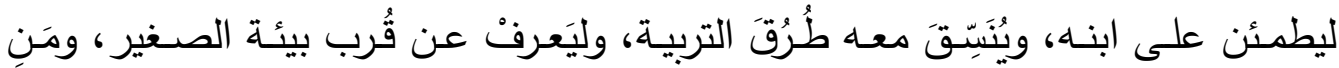

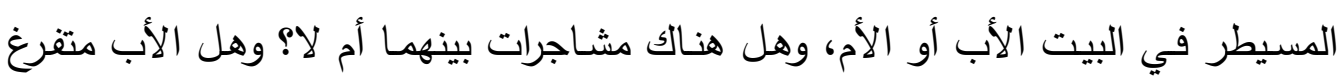


للتربية أم لا؟ وهل الأم لا تجلس مع ابنها إلا على مائدة الطعام أم تجلس معده في غير

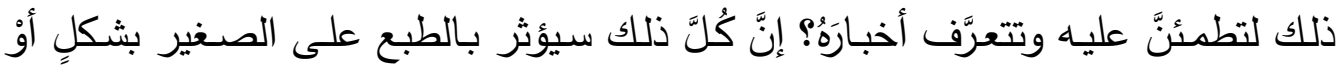

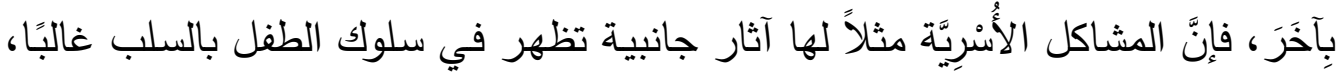

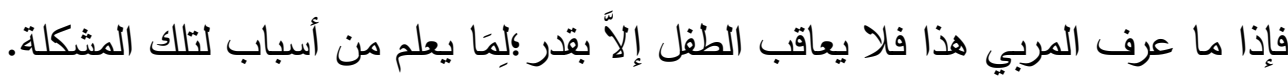

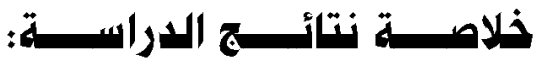

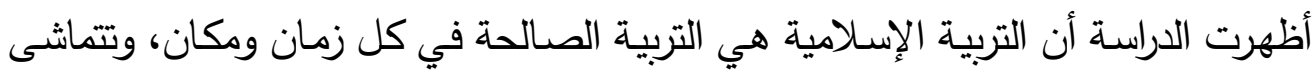

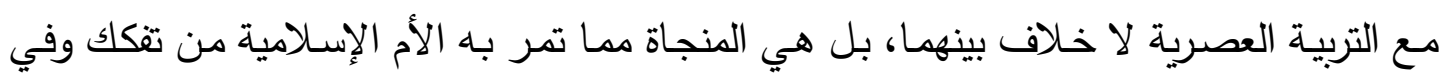
ظل انتشار التكنولوجية العصرية التي قد تؤدي إلى ابتعاد الأبناء عن هويتهم الإسلامية. اظهرت الدراسة وضوح مجالات التربية المختلفة واهتمام رسول الله صلى الله عليه وسلم لإنه

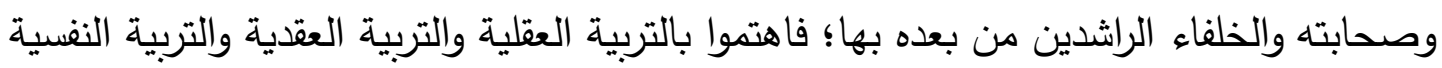
والتربية الاجتماعية والتر بية الخلقية والتربية الصحية والتربية الفكرية.

توصي الباحثة في نهاية بحثها بضرورة الاهتمام بالتربية الإسلامية في شتى مجالات

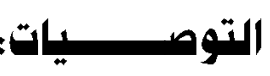
الحياة فهي: 1 - بربيةٌ عمليةٌ وليست نظريةً فهي حقيقة واقعية.

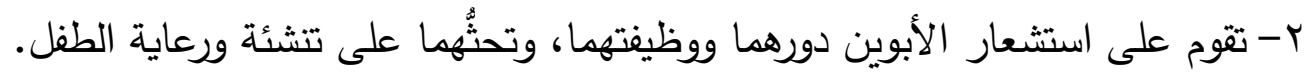

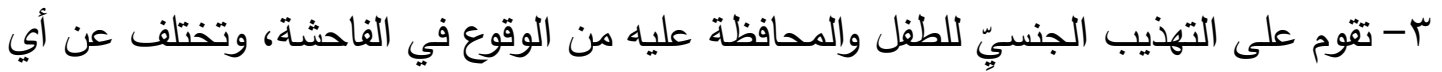

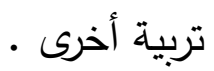

$$
\text { ع - تُنمي في الطفل برَّ الوالدين وطاعتهما. }
$$

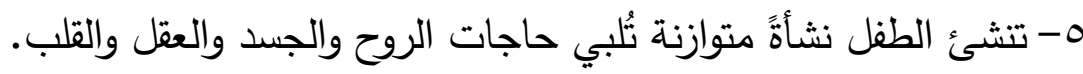

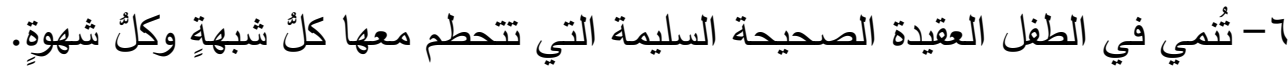

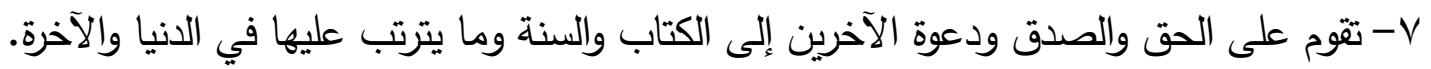
1- تُوزع المسؤولية بين الأب والأم تجاه تربية الأولاد.

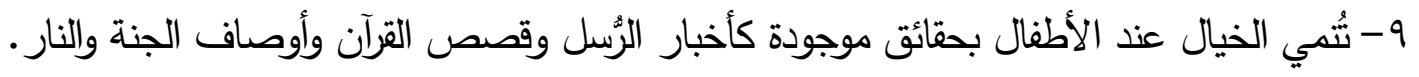

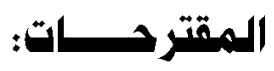

1- إجراء دراسات مشابهة عن كل خليفة من الخلفاء الراشدين. r- وضع تصور مقترح للاستفادة من مجالات التربية الإسلامية في مدارسنا. r- أجراء دراسات لقياس برامج تدريبية قائعة على مجالات التربية الإسلامية. 


\section{المراجــع والمصـادر}

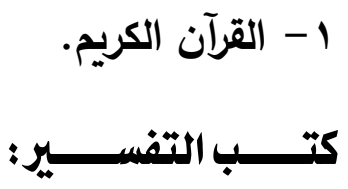

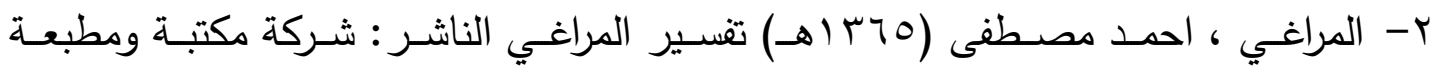



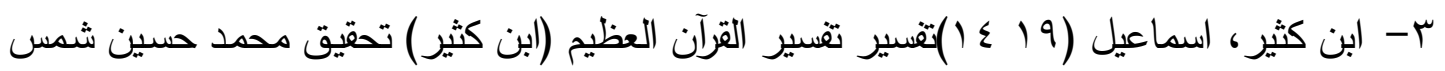

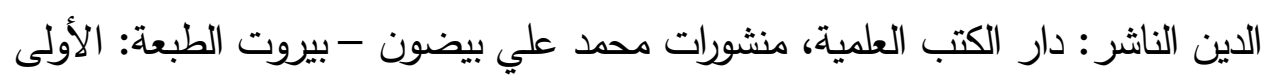

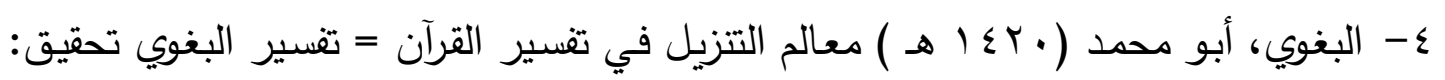

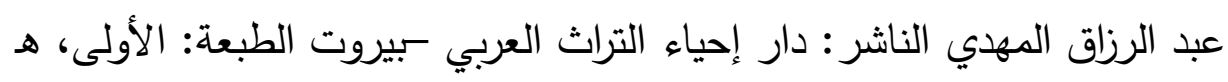

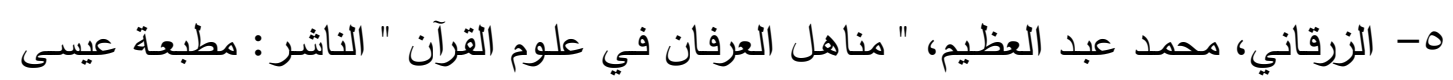
البابي الحلبي وشركاه، الطبعة: الطبعة الثالثة

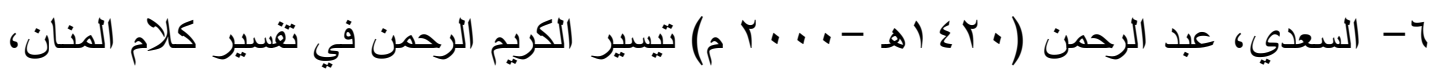

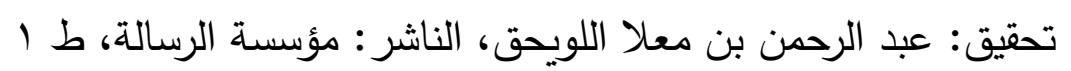

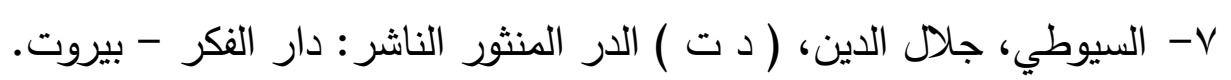

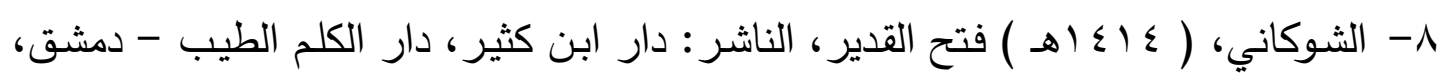
بيروت طا

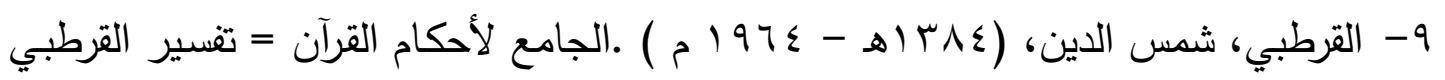

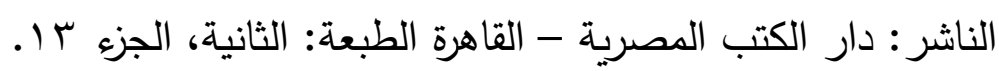
• ا- قطب ، سيد ( باء اهـ ) في ظـلال القرآندار الثـروق - بيـروت - القـاهرة الطبعـة: السابعة عشر.

\section{كتب تخريج الاحاديث ووكتب الاعلام وأخر مرتبة ترتيبا أبجديا :}

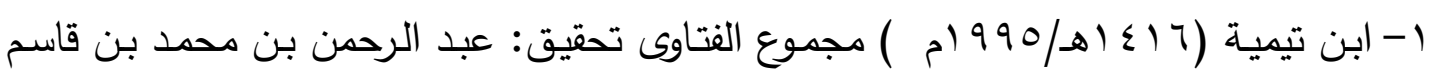

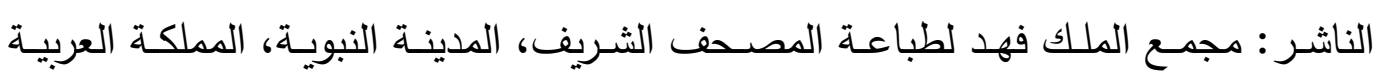

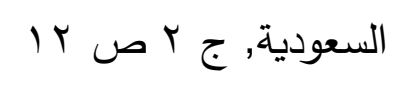

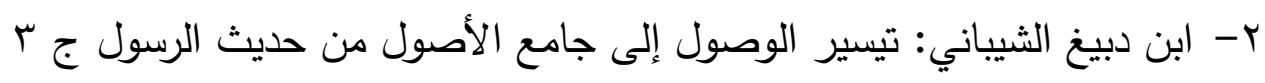

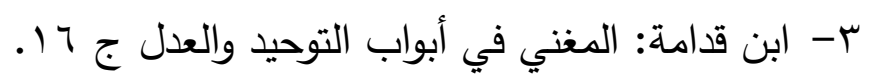




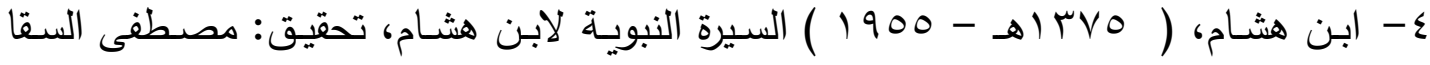
وإبراهيم الأبياري وعبد الحفيظ الثلبي، شركة مكتبة ومطبعة مصطفى البابي الحلبي وأولاده

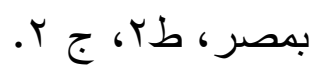

ه- الأصفهاني، الراغب ( د ت ): المفردات في غريب القرآن تحقيق: مركز الدراسات والبحوث

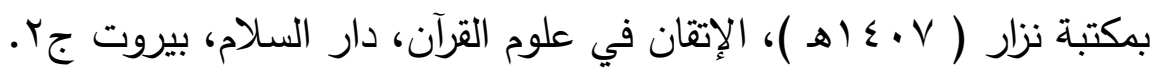

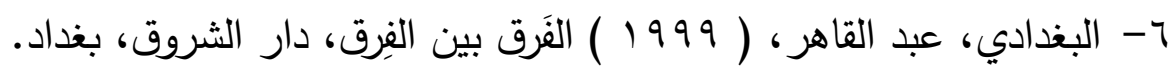

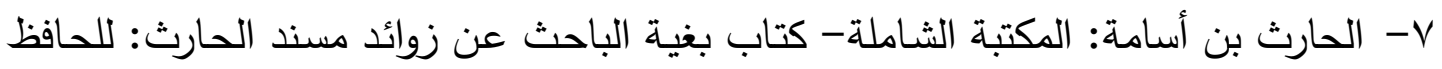

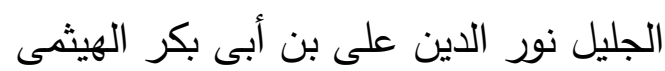
^- الزاوي، الطاهر أحمد ( به19 ( ) ) مختار القاموس، الدار العربية للكتاب، ليبيا.

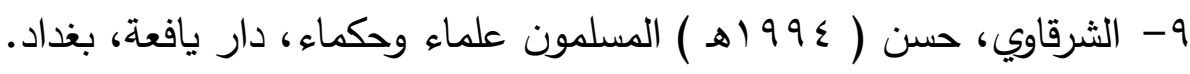

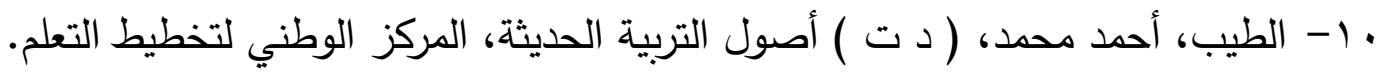

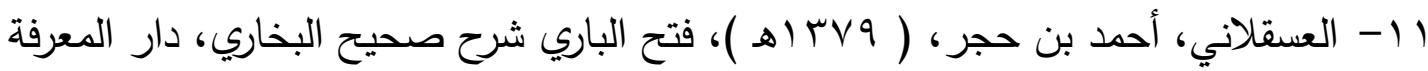

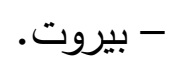

r ا ا الفنيش، احمد علي الفنيش ( د ت ) أصول التربية، الدار العربية للكتاب، ليبيا

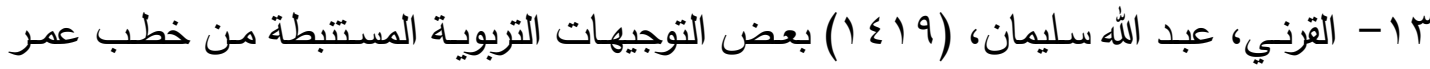

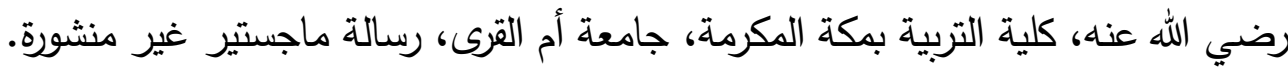

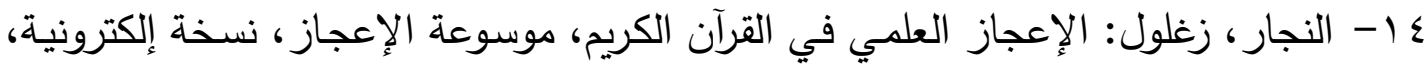

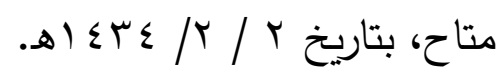

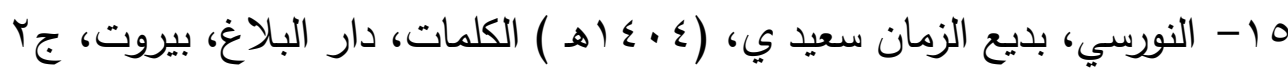

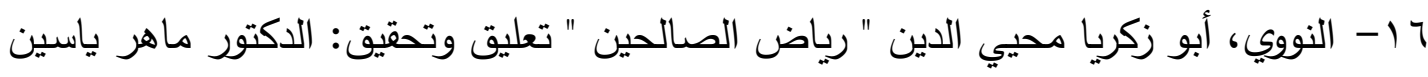

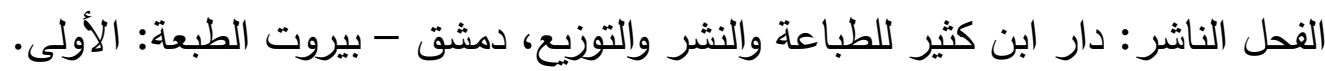
IV عليه وسلم) تحقيق: محمد فؤاد عبد الباقي الناشر : دار إحياء التراث العربي - بيروت.

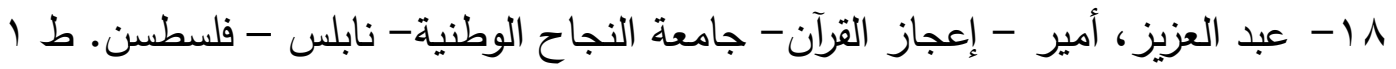



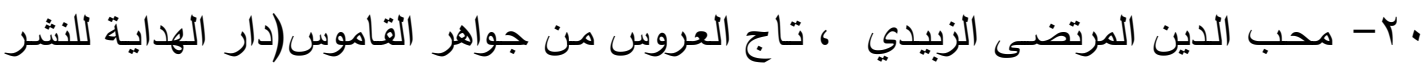

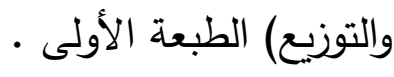




\section{Abstract}

The current study aims to identify the features of Islamic education in the era of Islam, through clarifying the conceptual framework of Islamic education, and the features of the fields of Islamic Education (faith, mental, psychological, empathy, congenital malformations, and social) in the era of Islam, and educational applications derived from Islamic Education in the era of Islam.

And the researcher used the descriptive approach, historical methodology and deductive methodology, the study showed the number of results, the most important: that Islamic education is good education in every time and place

In keeping with the modern education does not disagreement between them, the clarity of the various fields of education and attention to the messenger of Allah, may Allah bless him and companions of the Rightly Guided Caliphs after him; who are interested in one Mental Education, Education of history of Islam, psychological Education, Education of moral, social psychological, health Education, Education and intellectual Education.

\section{Index:}

Education- Islamic Education -The era of Islam. 